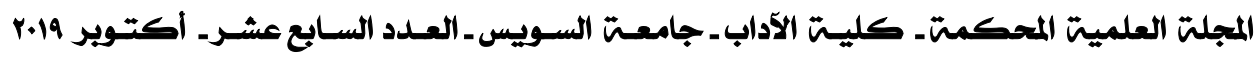

\title{
جيومورفولوجية الممرات الضخمة ونشأتها بالصحرائ الغربية في مصر
}

\author{
أشرف أبوالفتوح مصطفى

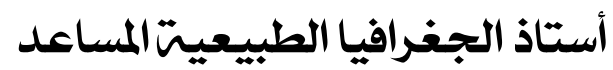 \\ كليت الآدابــجامعتمافيالسويس.
}




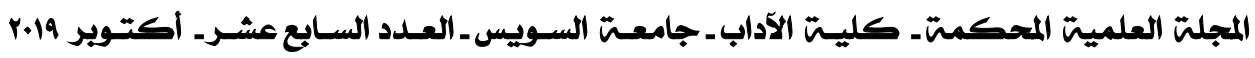




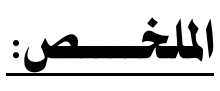

تعد ظاهرة الممر ات الضخمة (نظام الو ادي-الكدوي) أو كما يطلق عليها

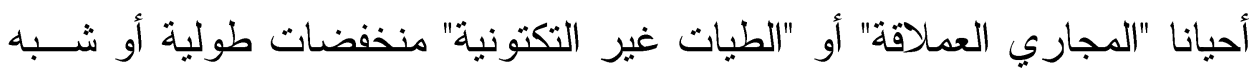

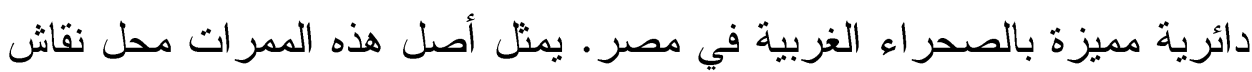

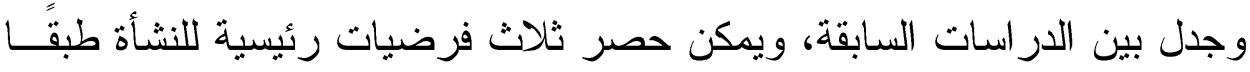

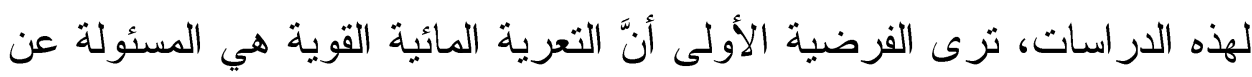

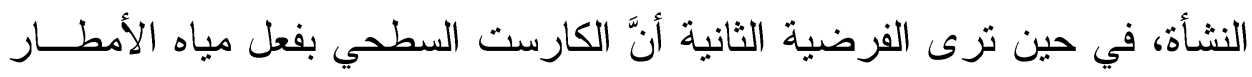

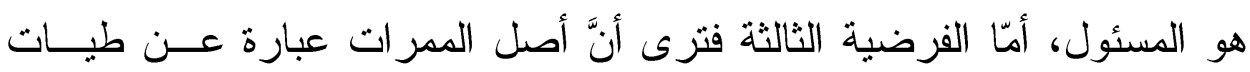

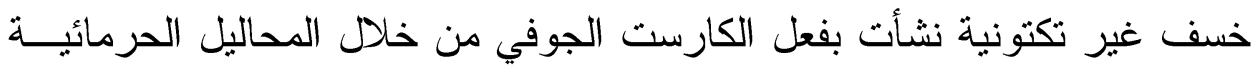
المتصاعدة من باطن الأرض. اعتمدت الدراسة الحالية على الخر ائط المختلفــة و المرئيات الفضائية و الدراسة الميدانية التفصيلية وذلك للتعرف على مورفولوجية الممر ات، كما أتاحت مكاشف بعض المحاجر و الرواسب الناتجة عن حفر آبـار

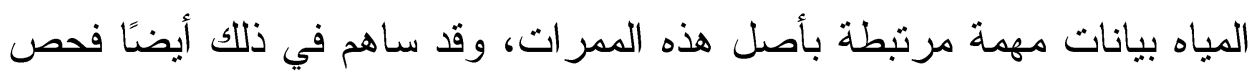

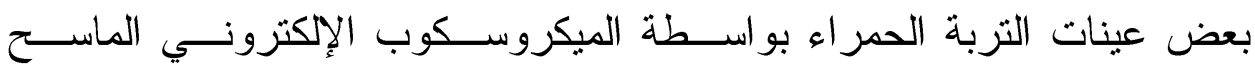

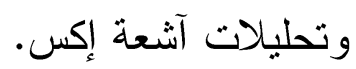

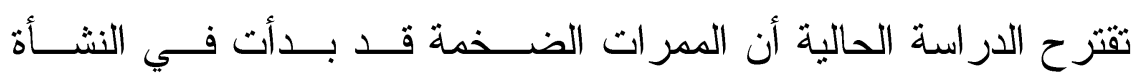

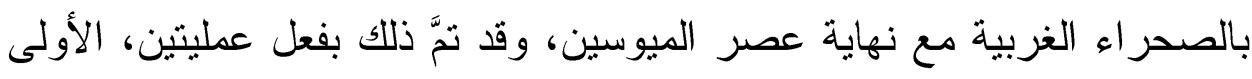

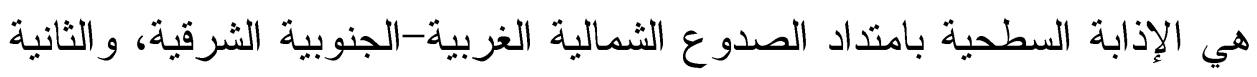

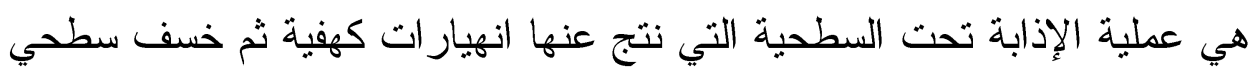
أدى إلى تكون طيات مقعرة غير تكتونية. أما عن السبب في نشاط هذه العمليات

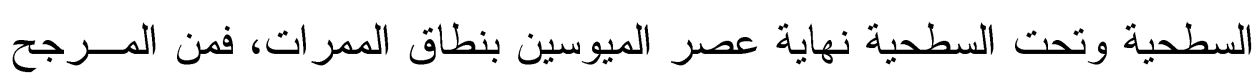

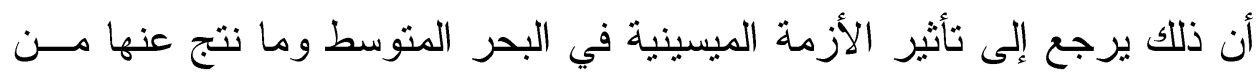

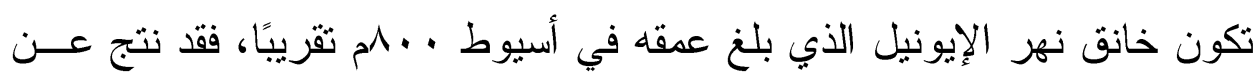


ذلك تجديد نشاط التعرية بالهضاب المحيطة، سواء كان ذلك من خــلال الإذابــة السطحية أو الخسف الناتج عن الانهيارات الكهفية. إلا أن نشاط تعميق الممرات

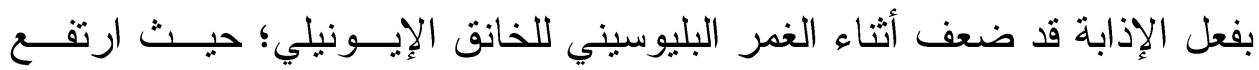
منسوب المياه الجوفية بالهضاب المحيطة مما أدى إلى ضعف نشــاط التعريــة عمومًا و عملية الإذابة بوجه خاص في تخفيض السطح وتشكيله. وبعــد انتهــاء تأثثر الغمر البليوسيني الذي استمر قرابة (Y) مليون سنة عــاد نشــاط تطــور المدرات مرة ثانية أثناء الفترات المطيرة فــي عصــر البليستوســين وأوائـلـ الهولوسين و أوسطه. الكلمات المفتاحية: الممرات الضخمة، الطيات غير التكتونية، الكارســ،

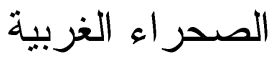




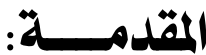

تُعد الممرات الضخمة -أو Giant flutes كما جاء ذكرهــا فــي دراســة

Brooks

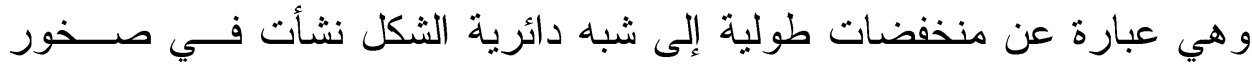
هضبة الحجر الجيري الإيوسيني الأدنى، يفصل بين هذه المنخفضات تلال طولية

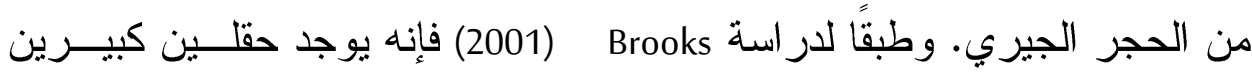

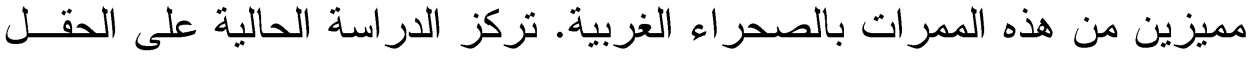

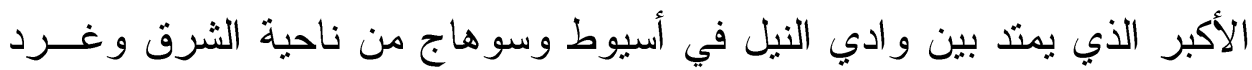

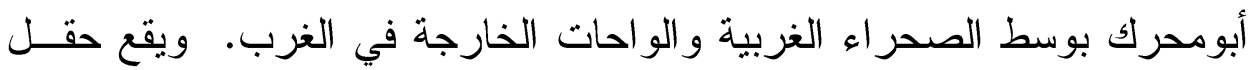
الممرات بين دائرتي عرض , N "

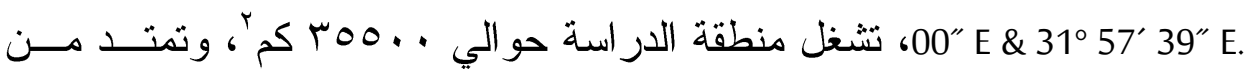

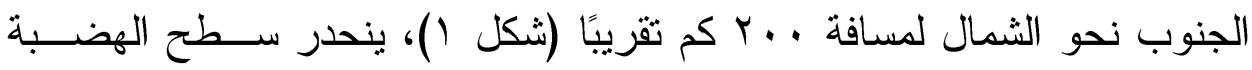

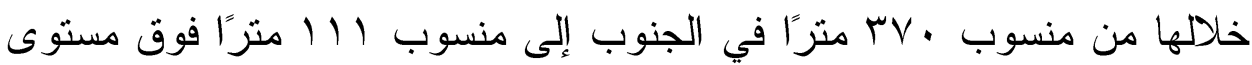

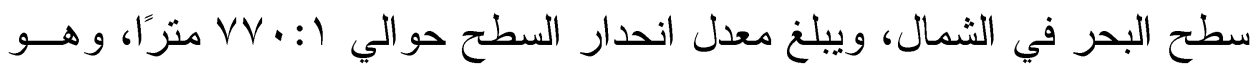
معدل انحدار قليل يشير إلى شبه استو اء سطح الهضبة في هذا الجزء وبالتـالي ترجيح ضعف الجريان السطحي. استخدم Sandford (1934) مصطلح "سهول حصوية مع حافات متو ازيــة" Beadnell (1898) كما جاء ذكر ها في خريطة "Gravelly plain with parallel ridges."

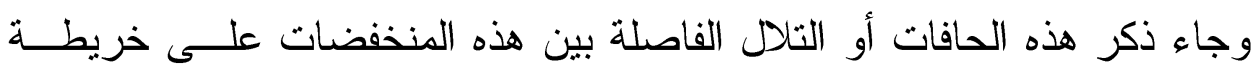

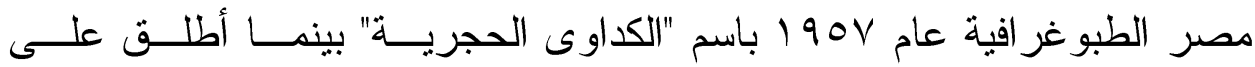

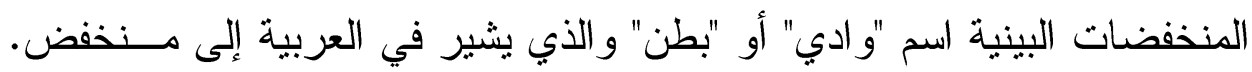

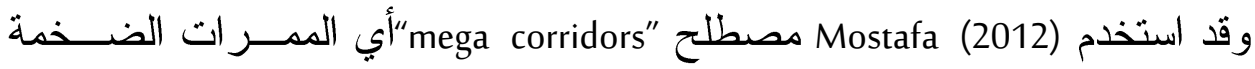

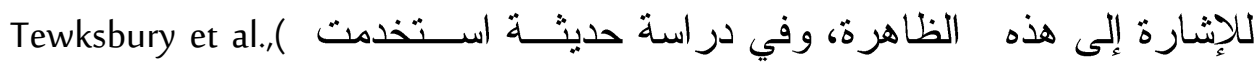


(2017 مصطلح "طيات مقعرة غير تكتونية" "non-tectonic synclines". أما الدر اسة الحالية فقد فضلت استخدام مصطلح "الممرات الضخمة" للإشارة إلى شكل هـذهـ الظاهرة كما يظهر ميدانيًا ومن خلال المرئيات الفضائية بصرف النظر مؤقتـا عن طريقة نشأتها.

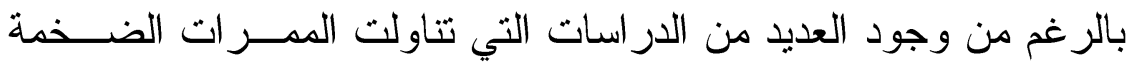

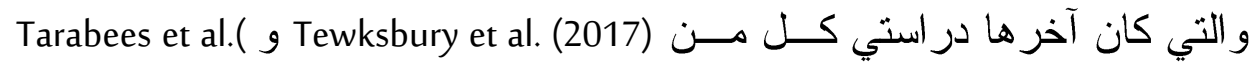
(2017إلا أن نشأة وتطور هذه الظاهرة لاتز ال محل نقاش ومجــال لتفســير ات مثتو عة، ويمكن حصر آراء وفرضيات النشأة في الدر اسات السابقة فــي ثــات فرضيات رئيسية: الأولى هي فرضية (2001) Brookes, التي يرى فيها أن نشـأة الممرات ترجع إلى "تعرية مائية قوية" catastrophic flood erosion تدفقت مباهها من الجنوب الثرقي نحو الثمال الغربي، وقد اعتمدت هذه الدراسة على مرئيات فضائية فقط. أما الثانية فهي فرضية النشأة من خلال "الكارست السطحي" التـي في

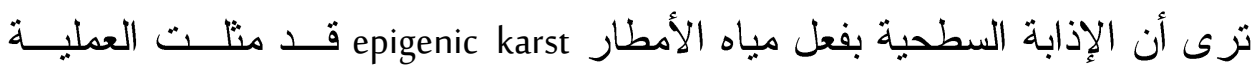
الرئيسية لنشأة الممر ات، وقد اعتمدت هذه الفرضية على ملاحظات حقليــة فـى نطاق الممر ات (Embabi, 2004; Mostafa, 2012) أما الفرضـــية الثالثــة فتــرى أن العملية الرئيسية التي أدت إلى النشأة هي "عملية سحب أو خسف غير تكتــــى" نتجت عن إذابة تمت على أعماق كبيرة مــن ســـح الأرض بفعـلـ المحاليـلـ

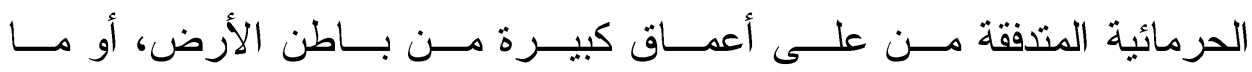
يسمى Tewksbury et al. 2017 and Tarabees et al. 2017) deep hypogenic karst). وقد اعتمدت الفرضية الأخيرة على مرئيات فضائية عالية الدقة، فضلا عن دراســـة

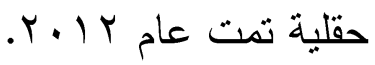


شكل (1) حقل الممرات الضخمة الرئيسي بالصحراء الغربية وموقعه

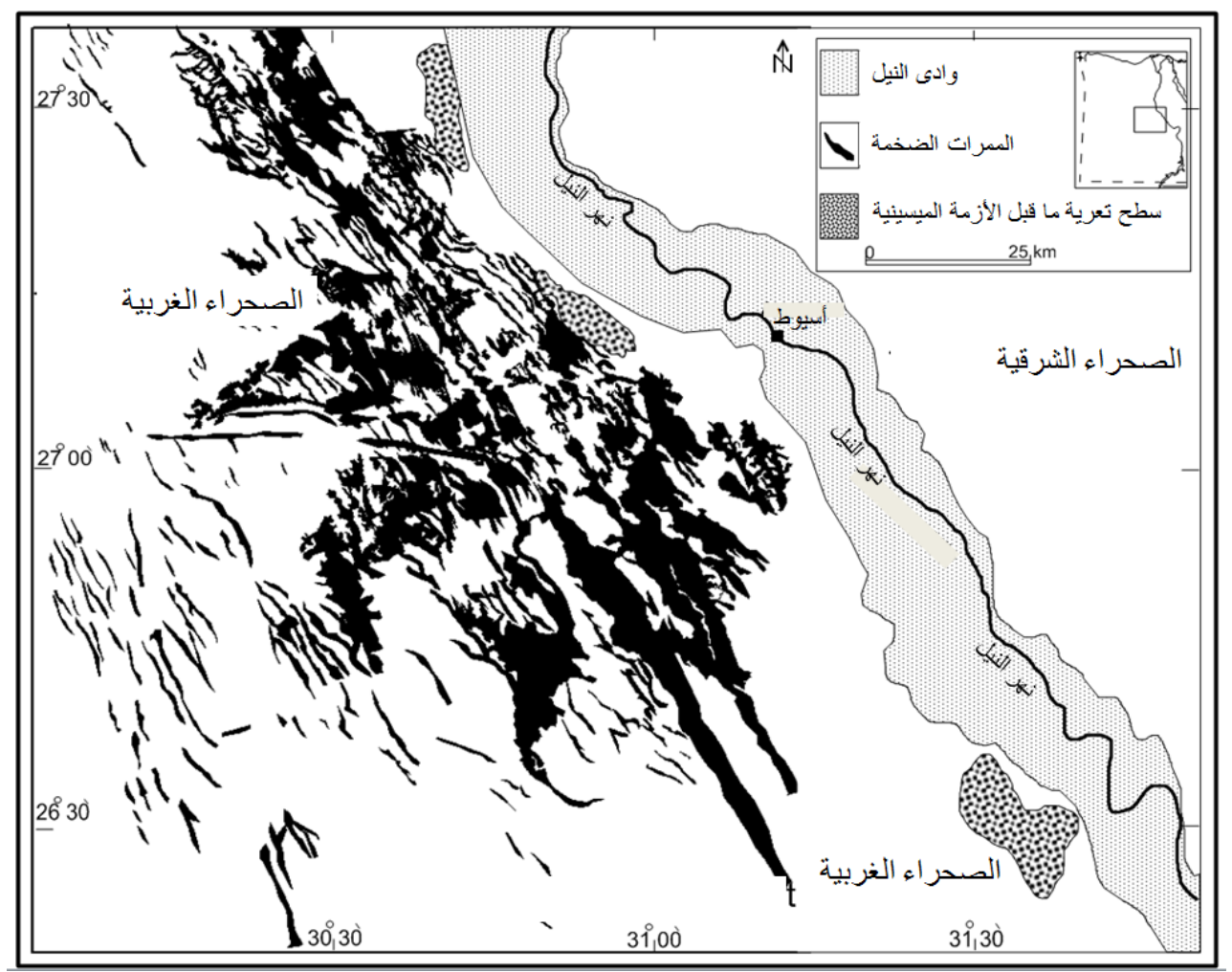

(المصدر: الملاحظات الحقلية و الخرائط الطبوغر افية ومرئيات جوجل ايرث)

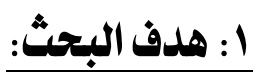

يهذف البحث الحالي إلى الوصول لأصل نشأة ظاهرة الممرات وتطور ها

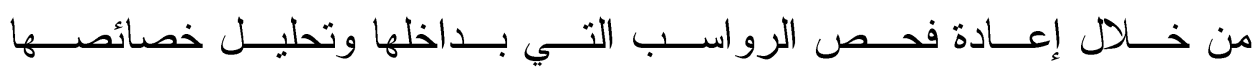
Tewksbury et al. الجيومورفولوجية، لاسيما في ضوء الفرضية الحديثة لدر استي (2017)و (2017) .Tarabees et al) ويرجع السبب في تتاول هــذا الموضــوع إلــى الاعتماد على العديد من الأدلة الجديدة التي لم تكن متاحة للار اسات السابقة، مثل تلك المرتبطة بنشاط المحاليل الحرمائية ودورها في عملية الكارســ، أو تلــك الأدلة الحديثة للكارست السطحي التي تم التوصل إليها من خلال مظاهر السطح المرتبطة بالإذابة السطحية، وقطاعات المحاجر، ونتــائج حفـر آبــار الميــاه 
المستخدمة في مناطق الاستصلاح الزراعي على قيعان الممرات، هذا فضلا عن

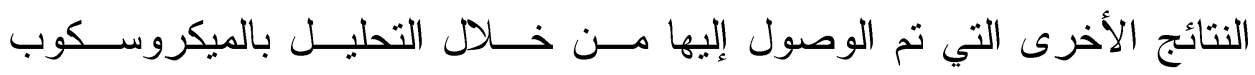
الإكتروني الماسح SEM.

\section{r: بريقة الدراسة:}

اعتمدت الدراسة بشكل رئيسي على العمل الميداني الذي بلغ أكثر مــن

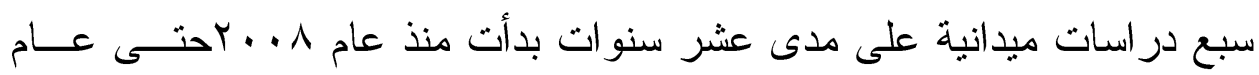

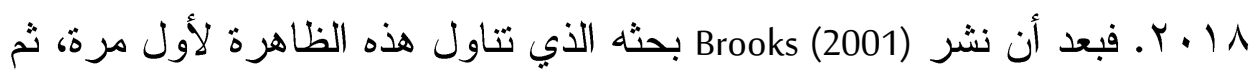

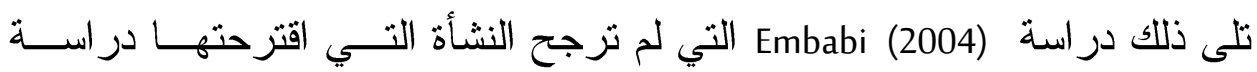
Brooks, 2001 حيث لفت إمبابي الانتباه إلى احتماليــة تضـــافر تــأثنير عمليـــة

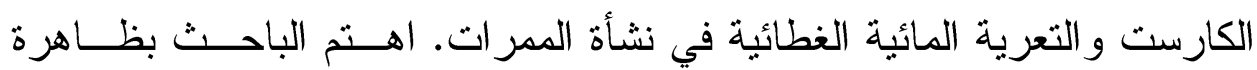

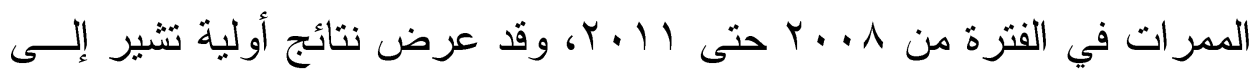

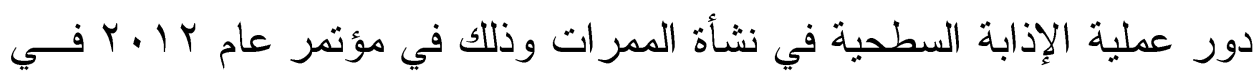
ليدن بهولندا.

وبالرغم من أن الدراسة الميدانية الأولى عام ^ . . ب بالإضافة إلى ثلاث

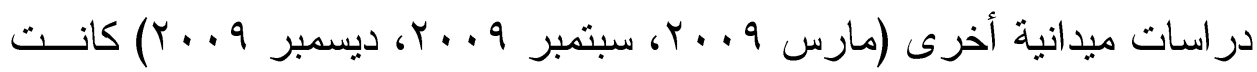
من أجل دراسة الممرات، إلا أنه قد رصد ظاهرة جديدة اعتبرت واحدة من أهم مظاهر الكارست غير العادية بالقرب من نطاق الممرات، وهو ما جعل الباحـــ

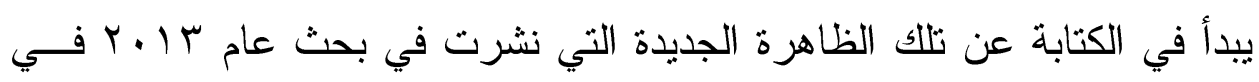
مجلة ACTA CARSOLOGICA بعنو ان: Paleokarst shafts in the Western Desert of عgypt: A unique landscape مظاهر الكارست بنطاق الممرات. وتلى ذلك إجر اء دراستين ميدانيتين في الفترة

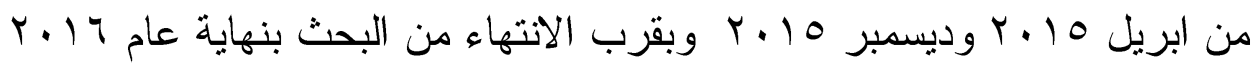
نُشر بحثان لفريق عمل أمريكي مصري مشترك ليضيف فرضية جديــدة لنشــأة 
الممر ات (Tewksbury et al. 2017 and Tarabees et al. 2017). لهذا تأخر نشر نتــائج البحث حتى يتسنى أخذ نتائج البحثين في الاعتبار، وتم إجراء در استين ميدانيتين

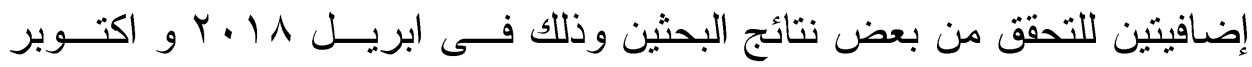

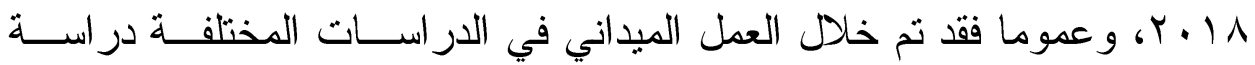
مورفولوجية الممرات وقياس أبعاد ( • ب) ممرا (الطول، و العــرض، و العهــق، و الاتجاه) ودر اسة خصائص انحدار ات الجو انب والقاع. كما تم رصد الظاهرات الجيومورفولوجية المختلفة داخل نطاق الممرات، وتم تسجيل التتــابع الرســوبي لقطاعات المحاجر بالمنطقة، فضلا عن فحص الرواسب الناتجة عن حفر آبـار

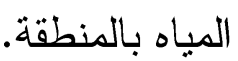

اعتمدت الدراسة الحالية على العديد من الخرائط الطبوغر افية التي تغطي

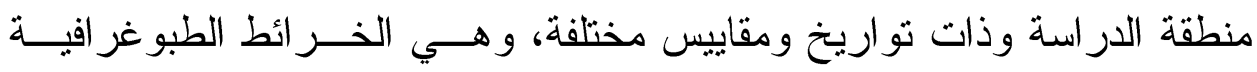

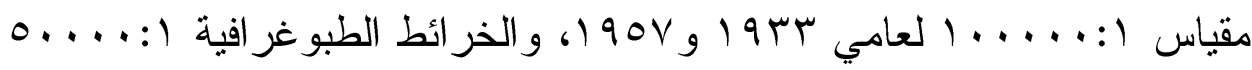
لعام •99 التي غطت أجزاء من المنطقة، هذا بالإضافة إلى الصــور المتاحــة على برنامج Google Earth Pro بدقة مكانية عالية بتو اريخ مختلفة، وقد منلت هذه الخر ائط و الصور وسيلة جيدة لدر اسة مورفولوجية الممر ات؛ حيث تــم در اســـة

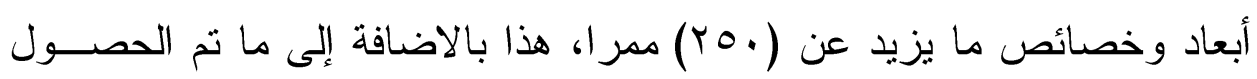
على بياناته ميدانيا. كما استعين بالخريطة الجيولوجية لمصر لوحة أسيوط مقياس

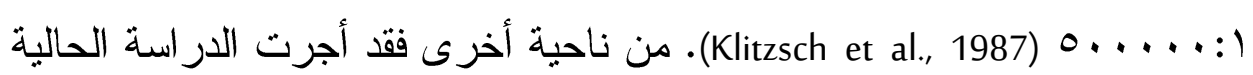
بعض التحليلات المعملية على رواسب قيعان الممرات، لاسيما رواسب التربـــة x ray الحمر اء وذلك من خلال الميكروسكوب الإكتروني الماسح (SEM) وتحليل diffraction المؤثزة فيها. 


\section{ب بيولوجية منطقة الدراسة:}

يغطي سطح منطقة الدراسة تكوينات الحجر الجيري التي ترجــع إلــى عصر الإيوسين الأدنى، وتتقسم هذه التكوينات إلى تكوين درنكه وتكوين المنيــا بشكل رئيسي (شكل r). يتألف تكوين درنكة من حجر جيري طباشيري منوسط إلى سميك الطبقات التي تميل للون الكريمـي إلـى الأبــيض التلجـي الغنـي

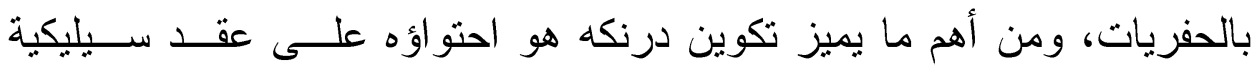
(Klitzsch et al., 1987; McBride et al., 1999; Abu El Ghar \& Hussein ور اقات صوان (2005. أما تكوين المنيا فقوامه حجر جيري جيد الطباقية أبيض إلـى رمسـادي (Klitzsch et al., 1987; Abu El Ghar \& Hussein 2005) الجيري التي ثرجع لأو ائل الإيوسين من طبقات شبه أفقية، وتتراوح درجة المبل

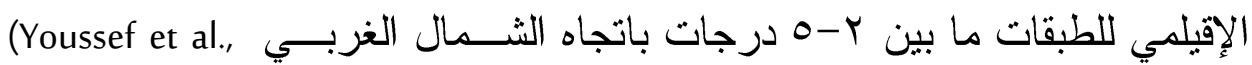
(1982 (شكل r). من ناحية أخرى فإن الاتجاه العام للصدوع يتفق مع الاتجـــاه الشمال الغربي_الجنوبي الشرقي والاتجاه الشمال الثــرقي -الجنــوب الغربــي،

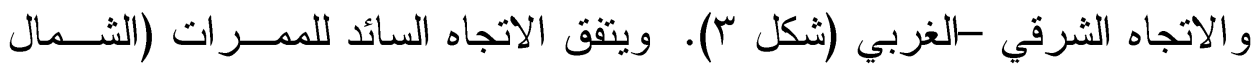
الغربي-الجنوبي الثرقي) مع الاتجاه السائد للمجموعة السائدة من الصدوع. ومن المرجح أن يكون هذا الاتجاه السائد للصدوع (الثمالى الغربي-الجنوبي الشرقي)

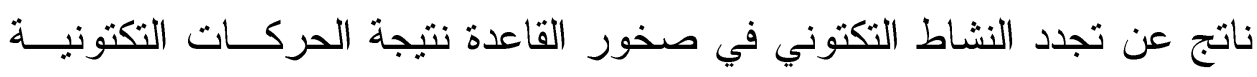
الناتجة عن انشقاق البحر الأحمر (Said, 1962; Youssef et al., 1982). يتشم بعــ (Youssef et al., هذه الصدوع بوجود حشو من الكالسيت و أكاسيد الحديد بــداخلها (1982. وتتسم الفو اصل الموجودة بالمنطقة باتخاذها ذات اتجاه الصدوع السائدة. يسود في نطاق الممرات العديد من الطيات المقعرة الصغيرة سو اء فــي تكــــين

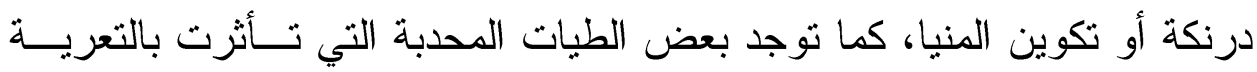

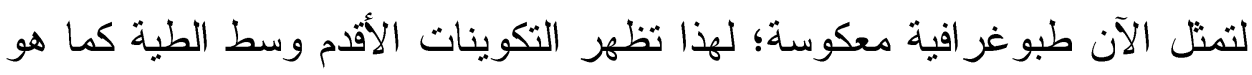
الحال في جبل جبيل (شكل ب). 
ع: الخصائص المورفولوجية للممرات:

ع-1:

تتخذ أغلب الممرات اتجاها خطيا منحنبا يغلب عليه الاتجــاه الثـــمالي

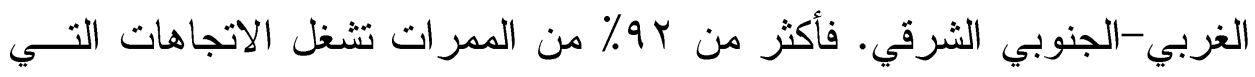

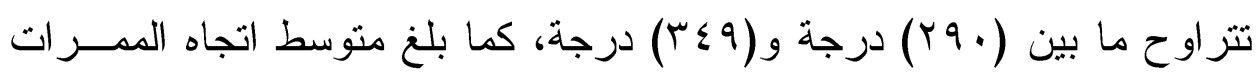

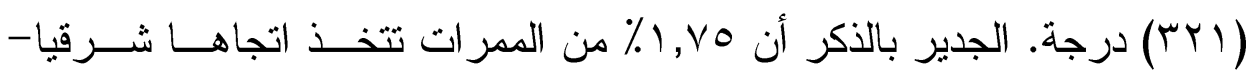

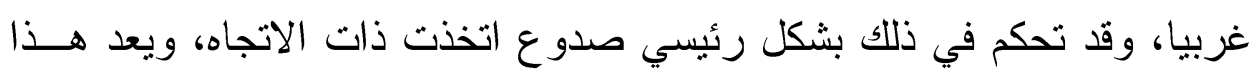

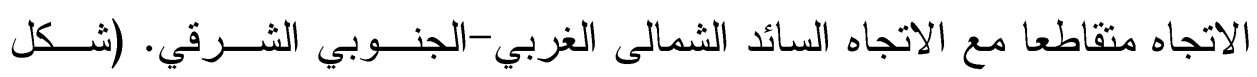
r)

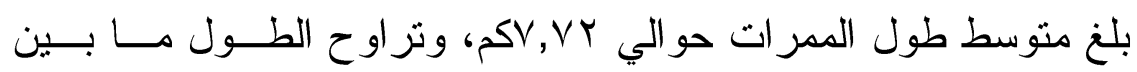

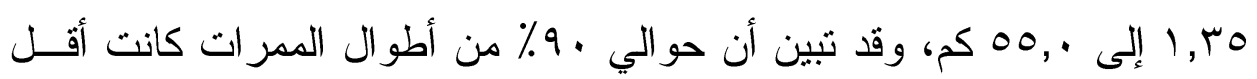

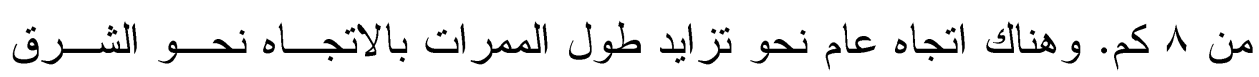

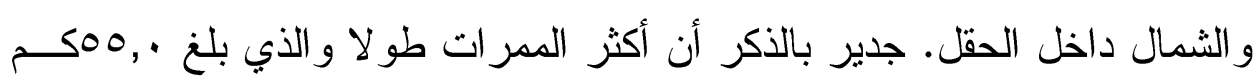

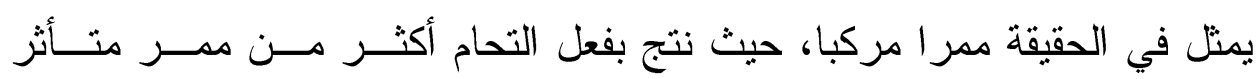

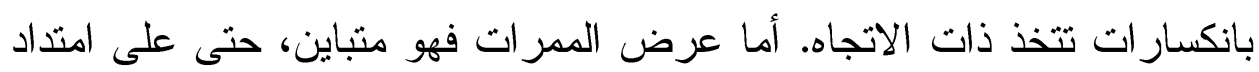

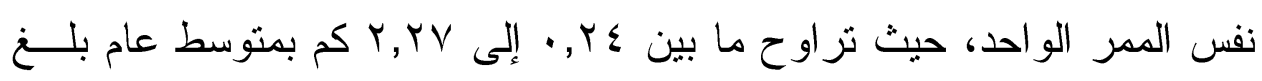

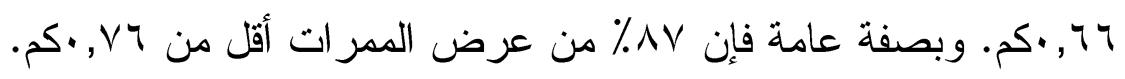




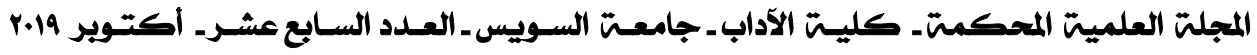

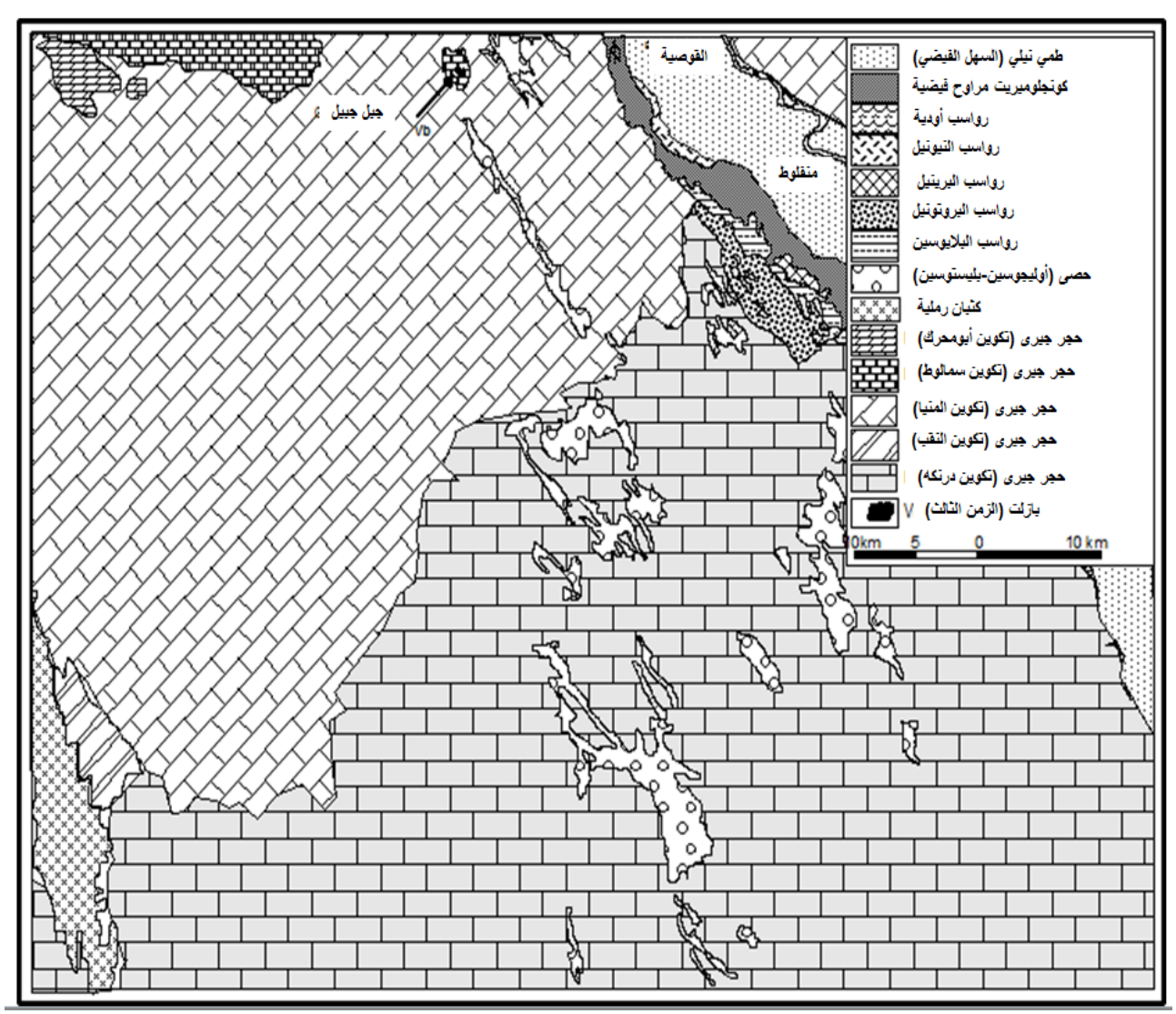

شكل (Y) خريطة التكوينات الجيولوجية بمنطقة الار اسة (Klitzsch et al., 1987)

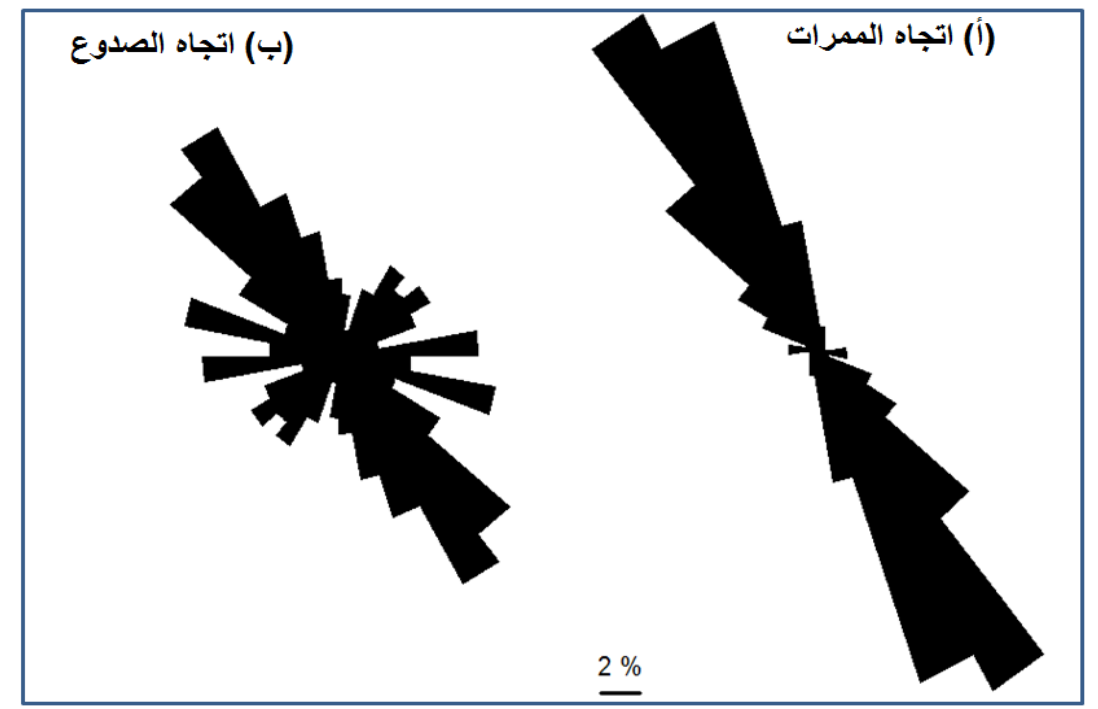

شكل (ץ) وردة اتجاه الممرات واتجاه الصدوع الرئيسية بمنطقة الاراسة 
تر اوح ارتفاع الجوانب الثرقية و الغربية بالنسبة لقاع الممرات ما بين 7

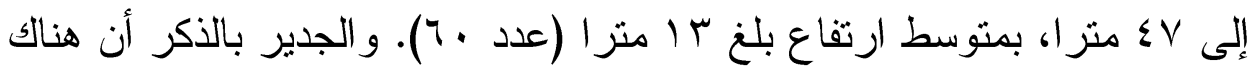
العديد من الممرات التي يغطي قاعها سمك كبير من رواسب التربــة الحمــر اء و البرشيا الحمر اء و الرمال المعاد تزسيبها بفعل المياه التي تجري داخل الممرات،

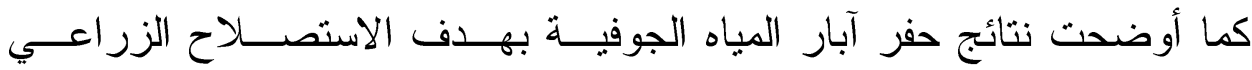
بالمنطقة، أن سمك هذه الرواسب قد تعدى في بعض الأحيان هب متر ا، وهو ما يعني أن ارتفاع جوانب الممرات قد يكون أكبر من ذللك؛ لأن أجزاء منها مدفونة تحت رواسبها. على الجانب الآخر فإن بعض هذه الممرات قد يخلو أغلب قيعانها من الرواسب. أما عن منسوب قيعان الممرات فهو يتز اوح ما بين . .. مثر ا في الجنوب وحو الي 111 متر ا في الثمال، وهو ما يعني أن قيعان هذه الممــرات يرتفع عن سطح السهل الفيضي في أسيوط (الذي يبلغ منســوبه. منـــر أفـي المتوسط) ما بين (آ منز ا إلى .0 ب منز ا (شكل ع).

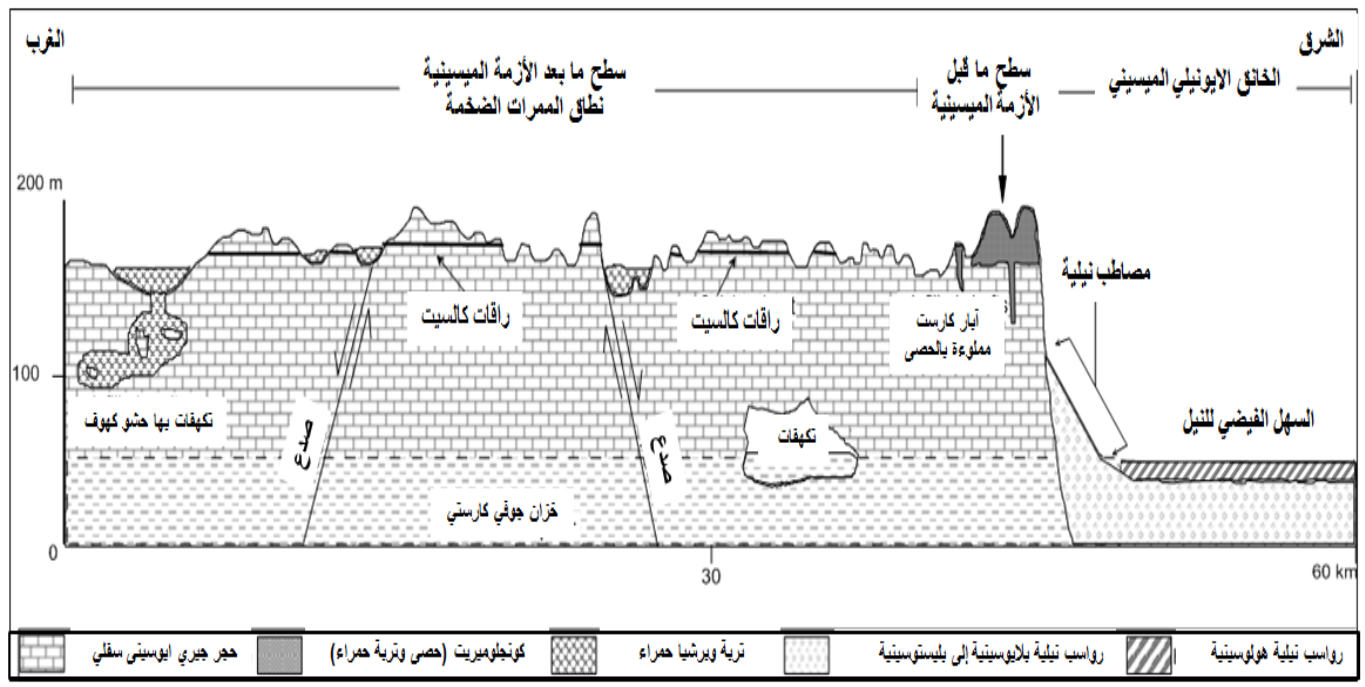

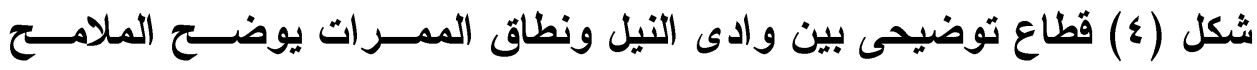
الرئيسية فوق السطح وتحته (المصدر : الملاحظات الحقلية والخر ائط الطبوغر افية ومرئيات جوجل ايرث) 


\section{ع - Y : الشكل:}

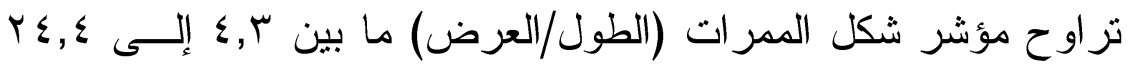
كما أن حوالي V0\% من هذه الممرات لها مؤشر شكل أقل من 0, • 1. هذا الشكل الطولي للممر ات قد يتحول أحيانا إلى شكل شبه دائري أو معقد عندما يلتحم أكثر من ممر، وقد ينتج عن تطور الحالة الأخيرة من الالتحام تكون ما يسمى الــبطن (منخفض أوسع نسبيا) كما يظهر على الخريطة الطبوغر افية لمصر عام سبو أ. يوضح شكل (0 و ؟) أنماطا مختلفة من الممرات في حقل الدراسة، يتباين شكل هذه الممرات ما بين منخفضات طولية مغلقة بالكامل إلى منخفضات مفتوحة من جانب أو أكثر • وقد تبين أن حوالي ر, 1ـ من الممرات مغلقة بالكامل، وحو الي

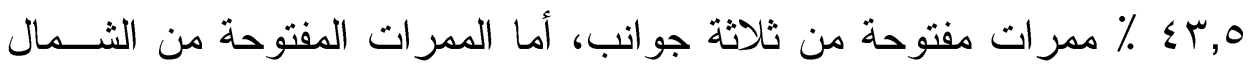
و الجنوب فهي تمنل 10 \% من إجمالى الممرات (عدد . ب0).

\section{ع-ب: الإحدار ات:}

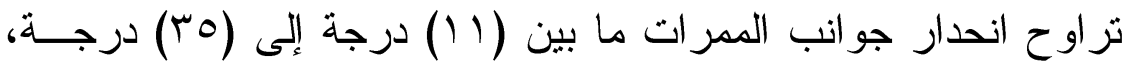
ويعد أكثر الدرجات تكرارا هي تلك التي تثراوح مابين (0) إلى (Y) درجة، كما بلغ متوسط الانحدار (YY) درجة. ويعد الانتقال مـــا بـين قـــاع المـــرات و الجو انب الثمالية و الجنوبية تدريجيا بالمقارنة بالجو انب الثـــرقية و الغربيــة. وبالنسبة لدرجات انحدار القيعان فقد تراوحت ما بين (1) إلى (0) درجات نحو وسط الممر أو باتجاه الشمال. 


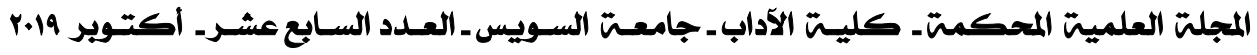

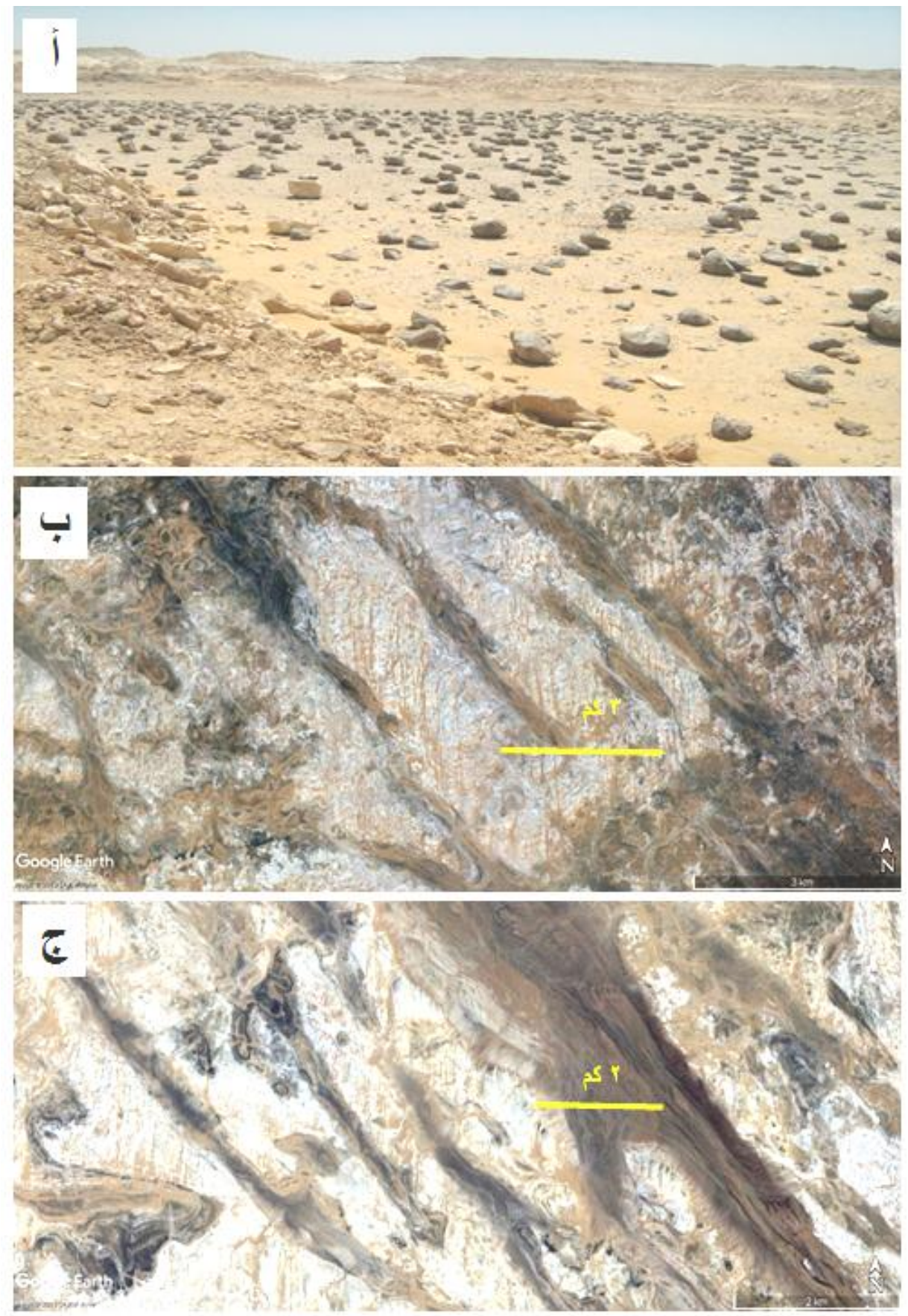

شكل (ه): أثكال مختلفة من الممرات الضخمة، حيث توضح (أ) صورة حقلية للممرات وقا

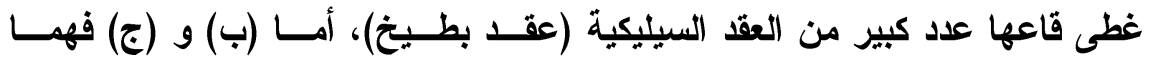

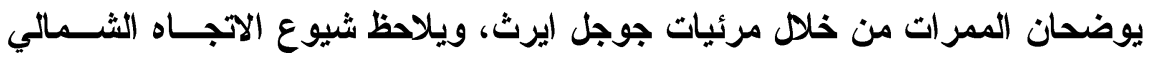

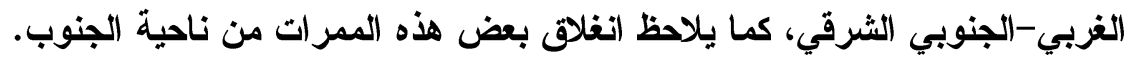




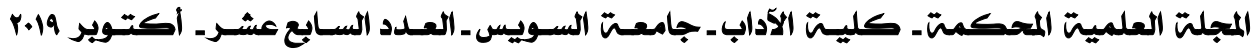
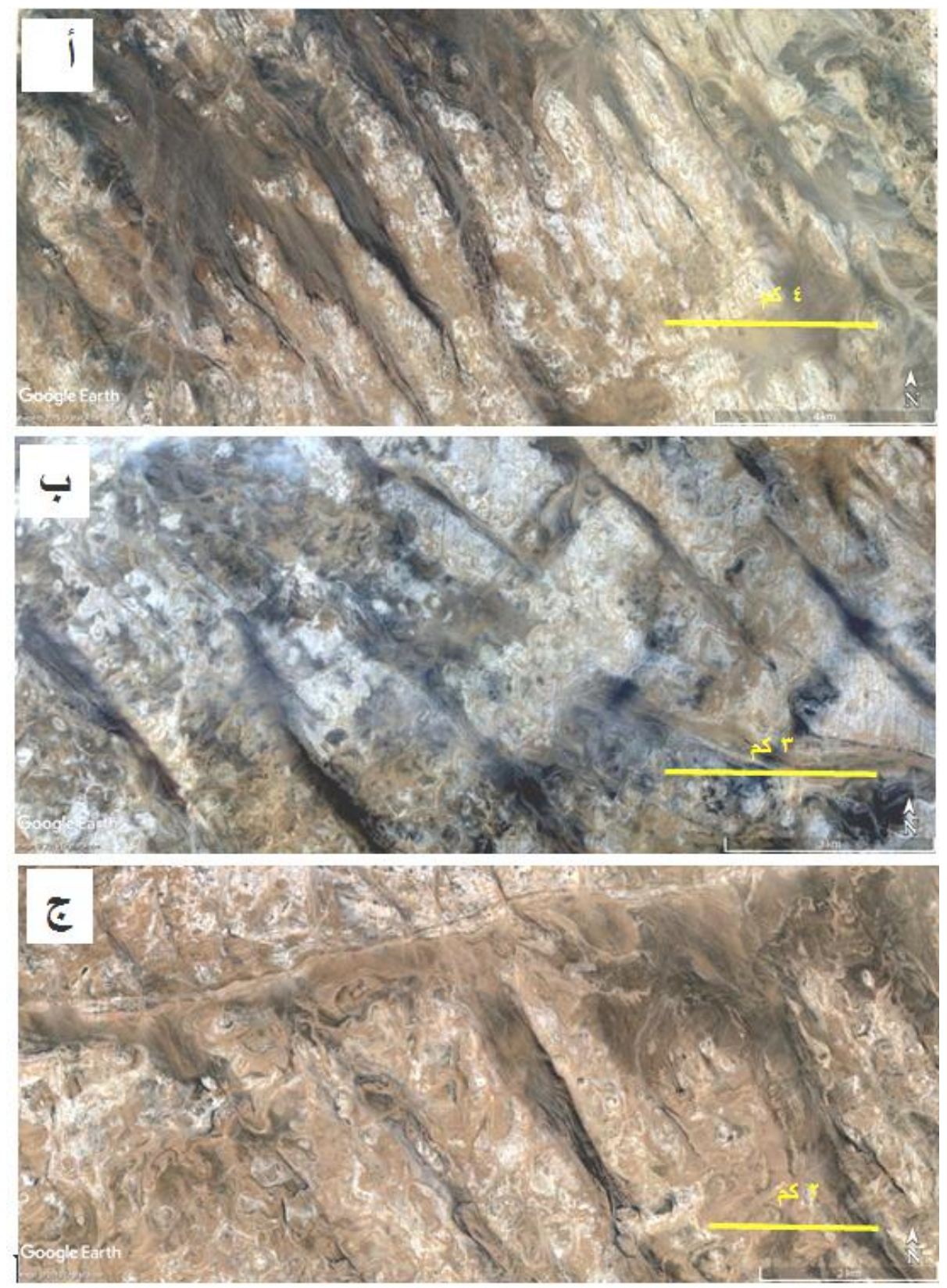

شكل (7) بعض الأنماط الأخرى من الممرات كما تظهر من مرئيات جوجـل (يـرث، حيــ

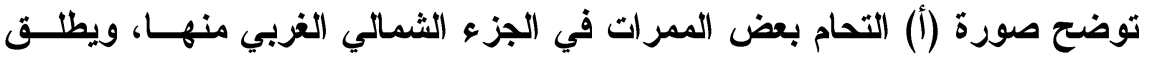

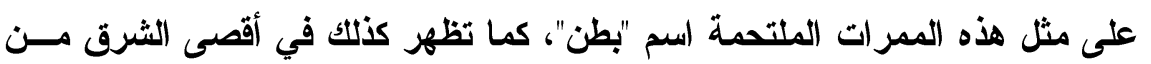

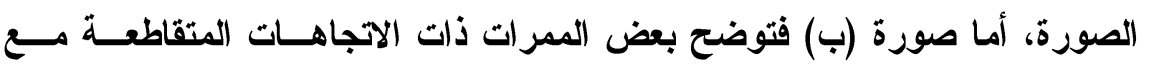

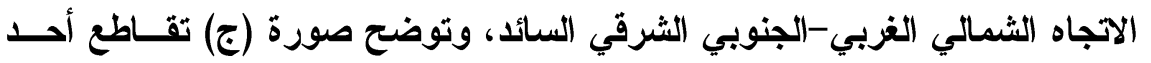
الممرات الثرقية الغربية المتأثرة بأحد الصدوع مع اتجاه الممرات السياتي السائدة. 
0 : الأشكال الجيومورفولوجية بالممرات:

0- - 1 - حقول عقد البطبخ:

عقد البطيخ أو ما يطلق عليها أحيانا "البطيخ المســخوط أو المصـقول" عبارة عن كتل صخرية سليكية كروية إلى شبه كروية مستديرة الحواف، تراوح

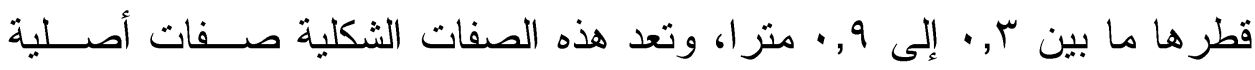

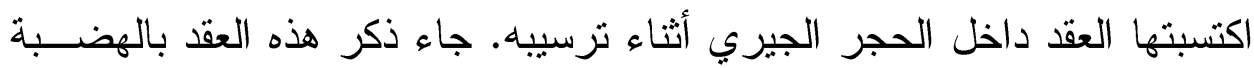
(Hume, 1925; McBride, الجيرية بالصحر اء الغربية في مصر في دراسات عديدة 1999; Embabi, 2004; Mostafa, 2013) و واسع في شكل حقول منفصلة سواء على قيعان الممرات أو على جو انبها (شكل

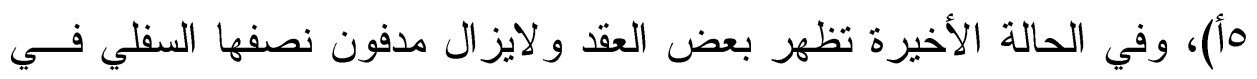

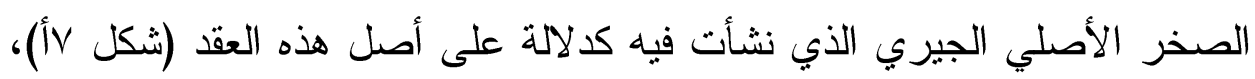
وقد صنفت حقول عقد البطيخ كمو اد متبقية عن عملية الكارست، بمعنى أن هذه لأه

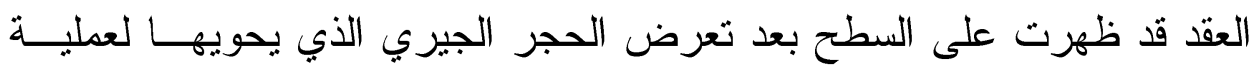
الإذابة، حيث خفض العجر الجيري وأزيل بمعدل أسرع نظر الطبيعـة نـأثره

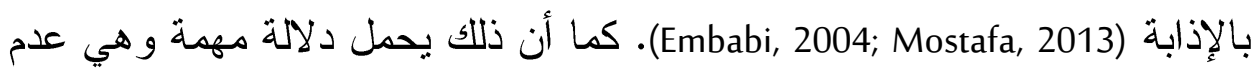

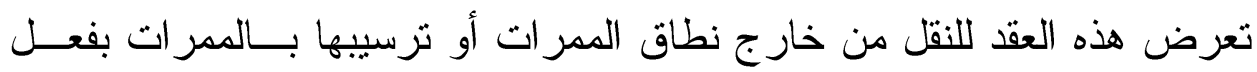

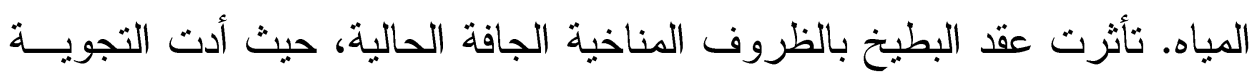
الحر ارية بفعل التسخين و التبريد السائدة بالصحاري الحارة إلى تفلق هذه العقـد، وقد يصل ذلك إلى حد تفنتها و اختفائها وتحولها إلى شظايا صخرية صغيرة حادة

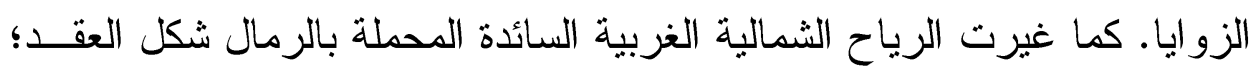
إذ تعرض النصف الثمالي منها للبرى حتى أزيل هذا الجزء من العقد بالكامل. 


\section{0-Y- السهول الحصوية:}

السهول الحصوية عبارة عن أر اضي مسنوية أو شبه مســتوية مغطـــــاة

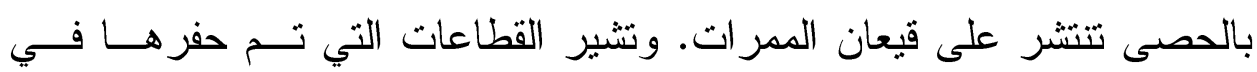

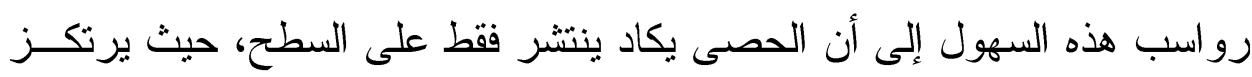

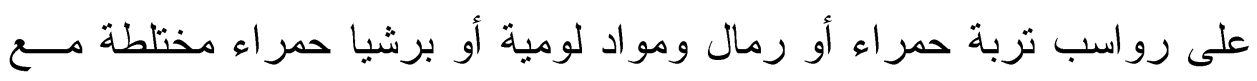

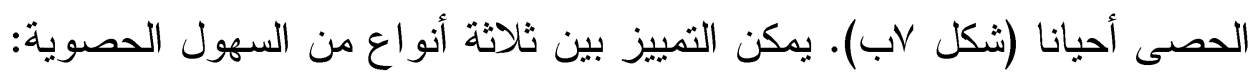

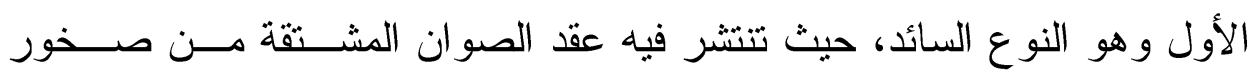

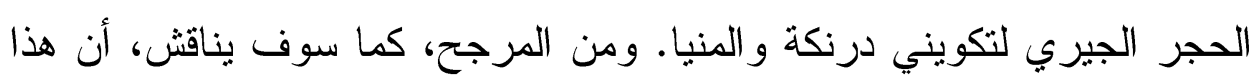

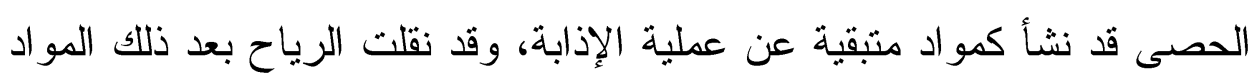

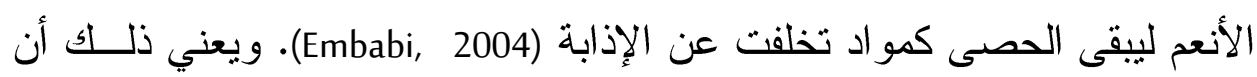

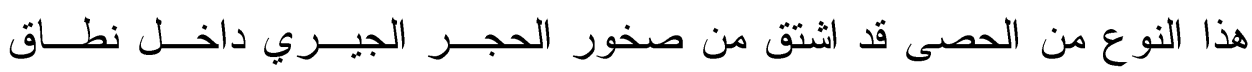

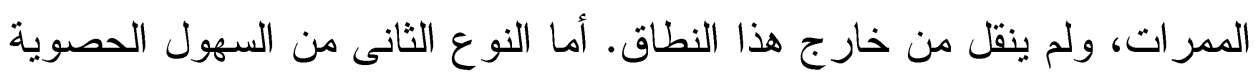

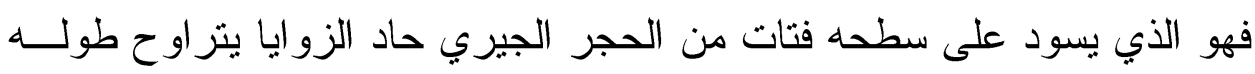

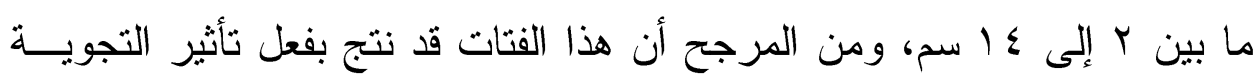

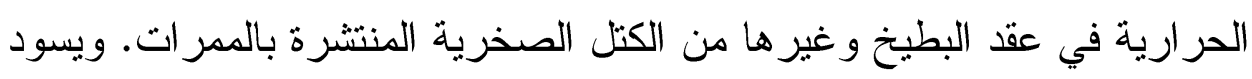

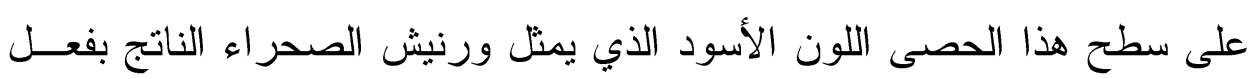

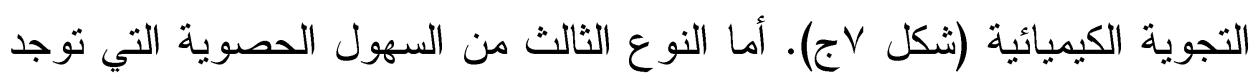

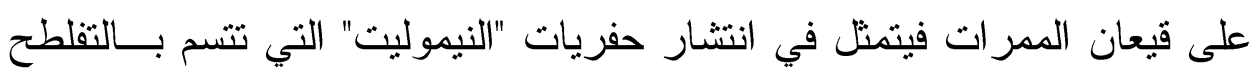

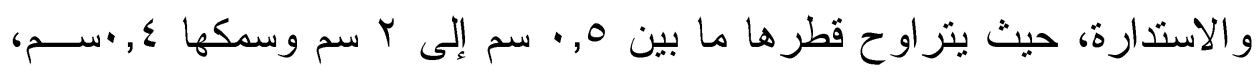

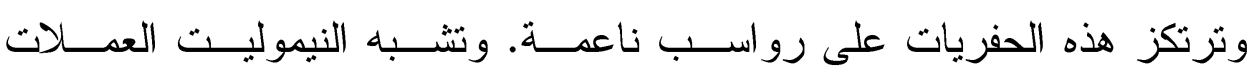

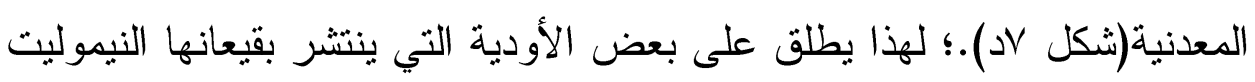

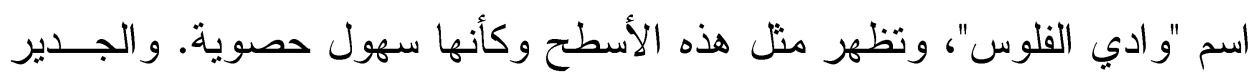

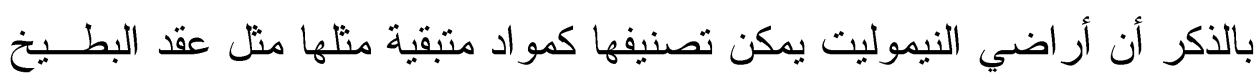

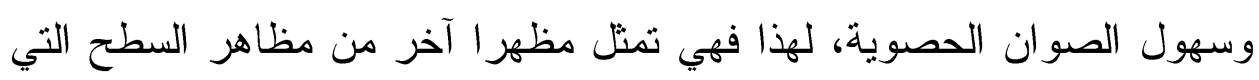
تشبر إلى عملية الإذابة السطحية للحجر الجيري. 


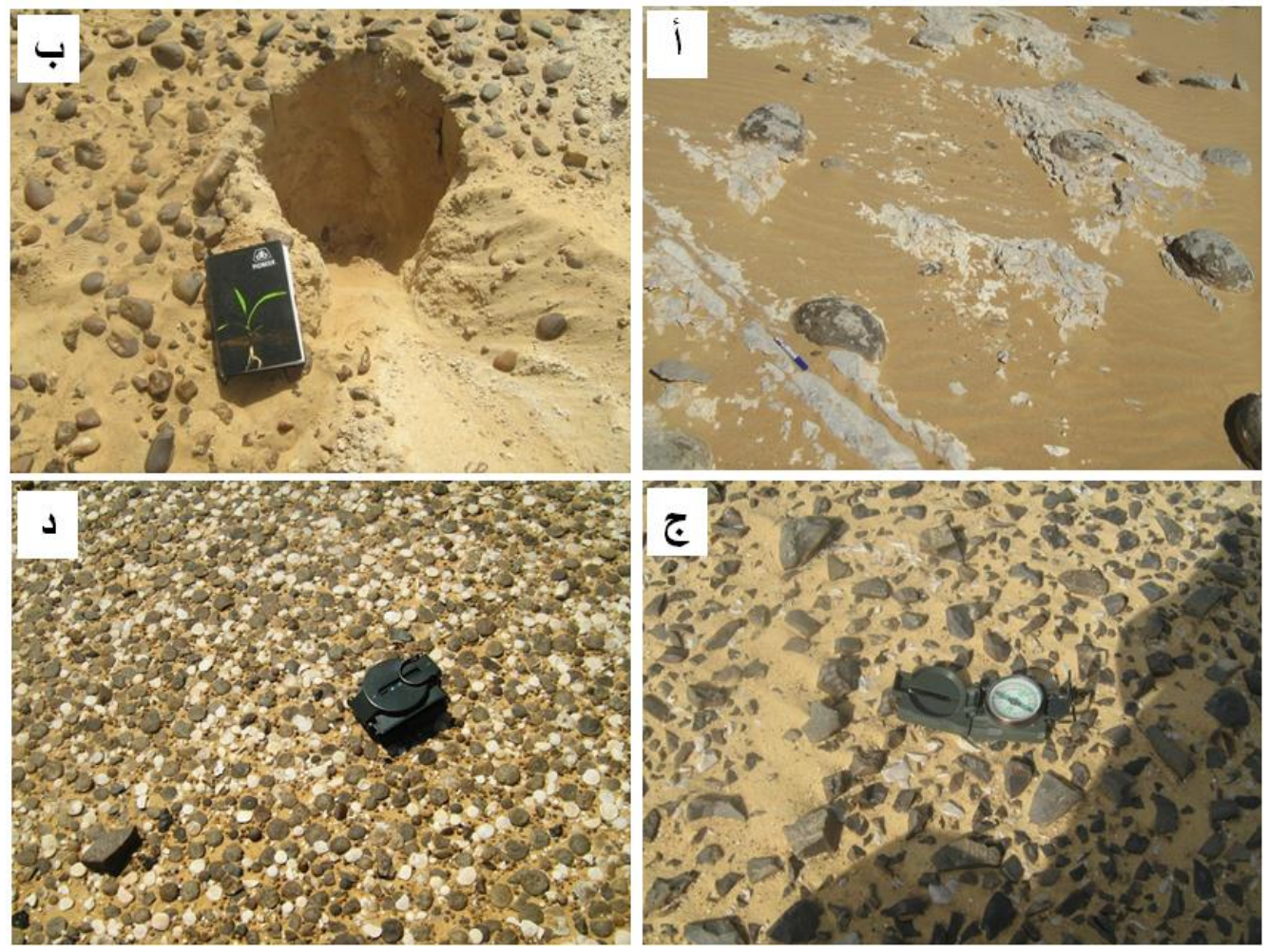

شكل (V) صور مختلفة لأنواع المتبقيات والرواسب المنتشرة في حقل الممرات، حيث توضح

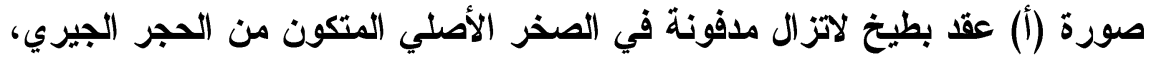

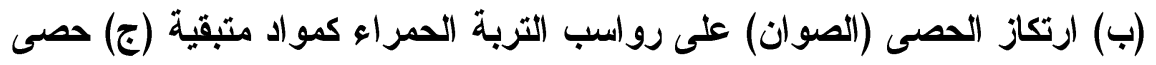

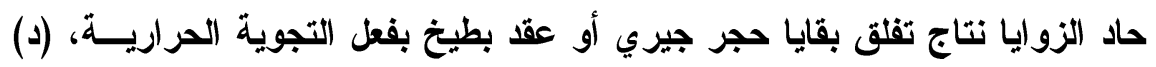

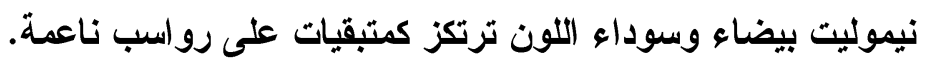

\section{ه-r: الأودبة الصغيرة والبرث:}

يقطع جو انب الممرات بعض الأودية الصغيرة التي يبلغ متوسط طولهــا

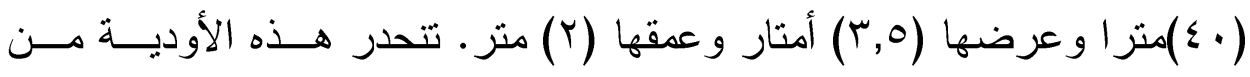
الكداوى الصخرية الفاصلة بين هذه الممرات نحو قبعان المنخفضات؛ لهذا ظهر في أخفض أجز اء قيعان الممرات برك تتجمع فيها المياه، وترنبط هـــه البــرك بمو اسم سقوط الأمطار، وبعد جفاف مياهها في فترات الجفــاف يتبةـى بعــ التجمعات النباتية في شكل أعشاب صحر اوية قد تستمر طو ال العام، كما تظهــر 
تشققات من المواد اللومية (رمال ناعمة ومواد جيرية) التي تركزت في أخفــ

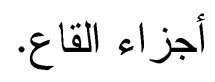

\section{ه-ع: خدوش الربياح والر اقات الرملية:}

ينتشر على الكداوى الحجرية الجيرية الفاصلة بين الممرات خدوش رياح صغيرة طولية يتفق اتجاهها مع اتجاه الرياح الثمالية الغربية السائدة. أغلب هذه

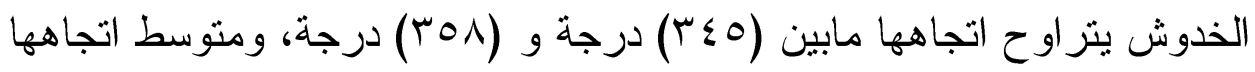
(10 (1) درجة. يبلغ منتوسط عرض الأجزاء المنخفضة ما بين عدة ســنتيمترات و(r,0) أمتار، كما يتر اوح العمق مابين (r, •) و (q, •)متر ا، أما الطول فهــو

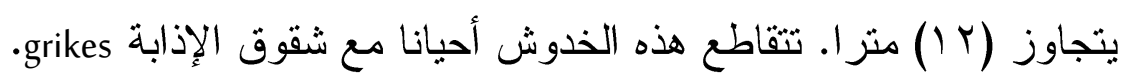

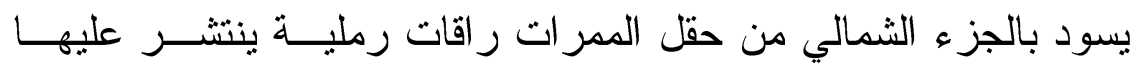
التموجات الرملية التي أرسبت وشكلت بفعل الرياح السائدة، بلغ أقصى ارتفــاع

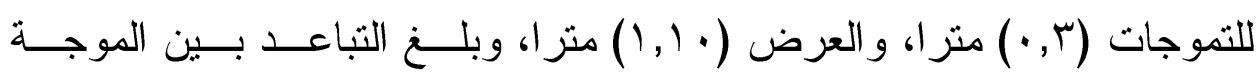
و الأخرى حو الي (1, ا ) متر ا. يغطي سطح هذه التموجات رمال خشنة إلى رمال

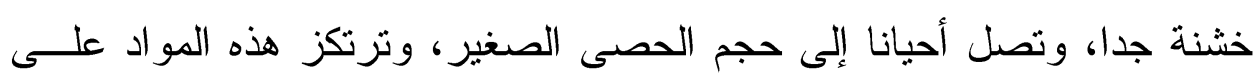

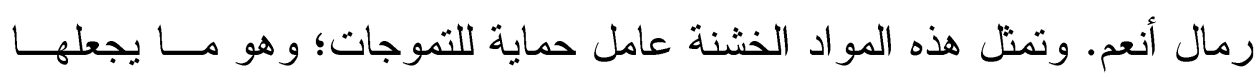
ثابتة وباقية لمدة طويله أمام تأثير الرياح القوية.

\section{-0-0: مظاهر الكارست:}

تتنشر مظاهر الكارست على سطح هضبة الحجر الجيـري الإيوســـــى الموجود فيها حقل الممرات، وقد تباينت هذه الأشكال ما بين شقوق إذابة رأسية

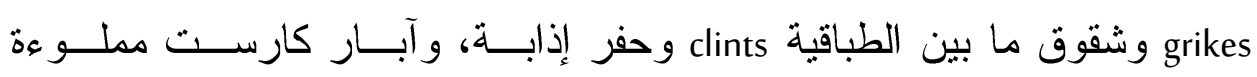
بالرواسب وكهوف وكهوف منهارة وكالسيت، وحصى متبقي عن الإذابة، وعقد (El Aref et al., 1987; بطيخ سليكية وتربة حمر اء وتلال كارستية مخروطية الشكل 
Sokkar, 1991; Ahmed, 1993; Kuper, 1996; Baajens, 1997; Brook et al., 2002; Embabi, 2004; Kindermann et al., 2006, Mostafa, 2007, Mostafa, 2013) اكتشف مؤخرا نوعا آخر من الكارست و الكهوف الذي ارتبط نشأثنه بالمحالبـلـ الحرمائية المتدفقة من باطن الأرض، وينتشر هذا النوع الجديد بالهضبة الجيرية على الجانب الغربي لو ادي النيل في أسيوط، حيث يمتد لعشــر ات الكيلـــومتر ات

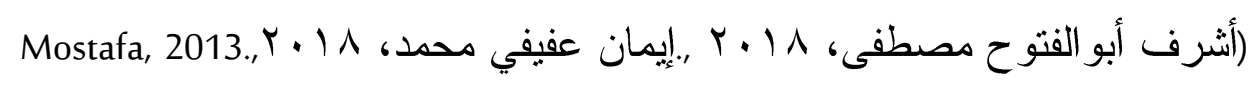
.(Mostafa, 2012.,

أما عن شقوق الإذابة بالكداوى الجيري الفاصلة بين الممرات فقد تراوح

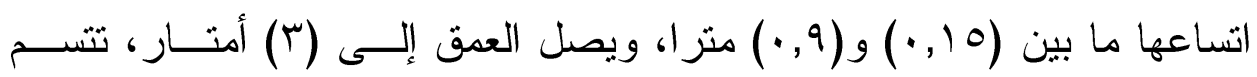
جو انبها بالعمودية وقد بملأها أحيانا كونجلومبريث أو تربة حمراء. تتخذ شقوق الإذابة اتجاها شمالبا غربيا-جنوبيا شرقيا، وشــماليا شـرقيا-جنوبيــا غربيــا، وشرقيا-غربيا، و هو ذاته اتجاه الفو اصل و الصدوع السائدة بالمنطقة. أما شقوق

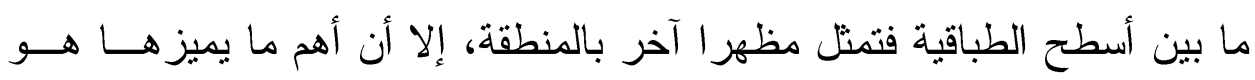
وجود راقات كالسيت أرسبت داخلها، تعدى سمك هذه الر اقاث أحيانــا المتــر، وينتشر الكالسيت في شكل راقات متتابعة تنتظم فيها بلور ات الكالســبث بشــل عمودي على سطح الطباقية (شكله)، تمثت هذه الراقات لعدة كيلومثرات داخـلـ تكوين درنكه. ومن المرجح ارتباط هذه الراقات بسطح عدم تطابق في تكـــين درنكه.

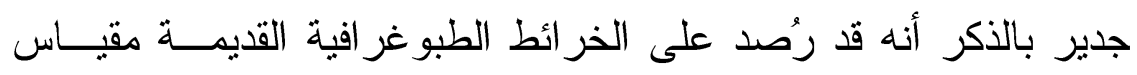
1: . . . . . لسنة سبو الوحة منفلوط غرب أسيوط، عددمن الكهوف التي لــ يتمكن من التعرف عليها ميدانيا؛ نظر التغير ملامح منطقة الكهوف بفعل التحجير و عمليات الاستصـلاح الزر اعي، فضلا عن عمليــات ثشــيبد الطــرق الجديــدة بالمنطقة. إلا أن من أهم مظاهر الكارست بنطاق المدــرات وجــود الكهــوف المنهارة التي تم التعرف عليها في قطاعات المحاجر التي استخلت قيعان بعــض 
الممرات، حيث رصدت هذه الكهوف وهي ممتلئة برو اسب مختلفة مـن تربـــة

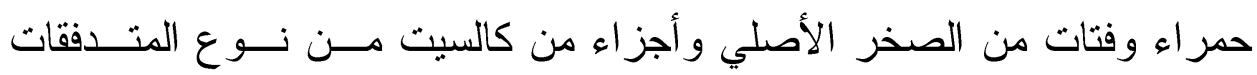
الكلسية flowstone (الألباستر المصري)، هذا فضلا عن كتل من الحجر الجيري، تعرض هذا الحشو من المو اد للتماسك بفعل كربونات الكالسيوم مكونــا برشــيا كهوف (شكل 9). ومن المرجح أن هذه المواد قد تدفقت من أعلى بفعل انهيارات كهفية.

من ناحية أخرى فقد كشفت عمليات حفر آبار مياه الــري فـــي قيعـان الممرات عن وجود فجوات كهفية عديدة اخترقتها آلات الحفر، ولم يستدل مــن خلال الرواسب المستخرجة على أي رواسب تشير إلى نشاط محاليل حرمائيــة،

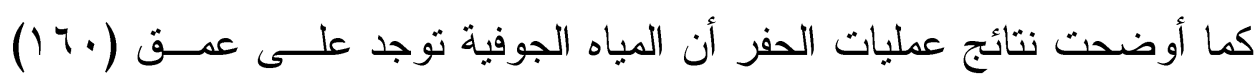
منر ا غرب منفلوط، ويقل هذا العمق بالاتجاه نحو الشمال إذ تصــل إلـى (.9) متر ا غرب ديروط.

\section{7}

\section{7- 1 :التربة الحمراء (أو البرشيا الحمر اء):}

التربة الحمر اء إحدى متبقيات عملية الإذابة، وهي عبارة عـن رمـــال ومواد كلسية إلى صلصالية يميل لونها إلى الإحمرار . وتعد التربة الحمر اء أكثر

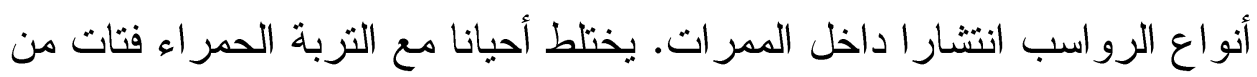
الحجر الجيري حاد الزوايا الذي يتباين طوله ما بين (0, •) و (1, ) سم. 


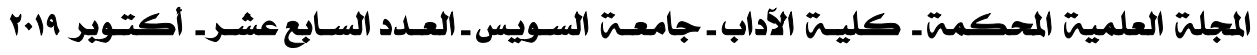

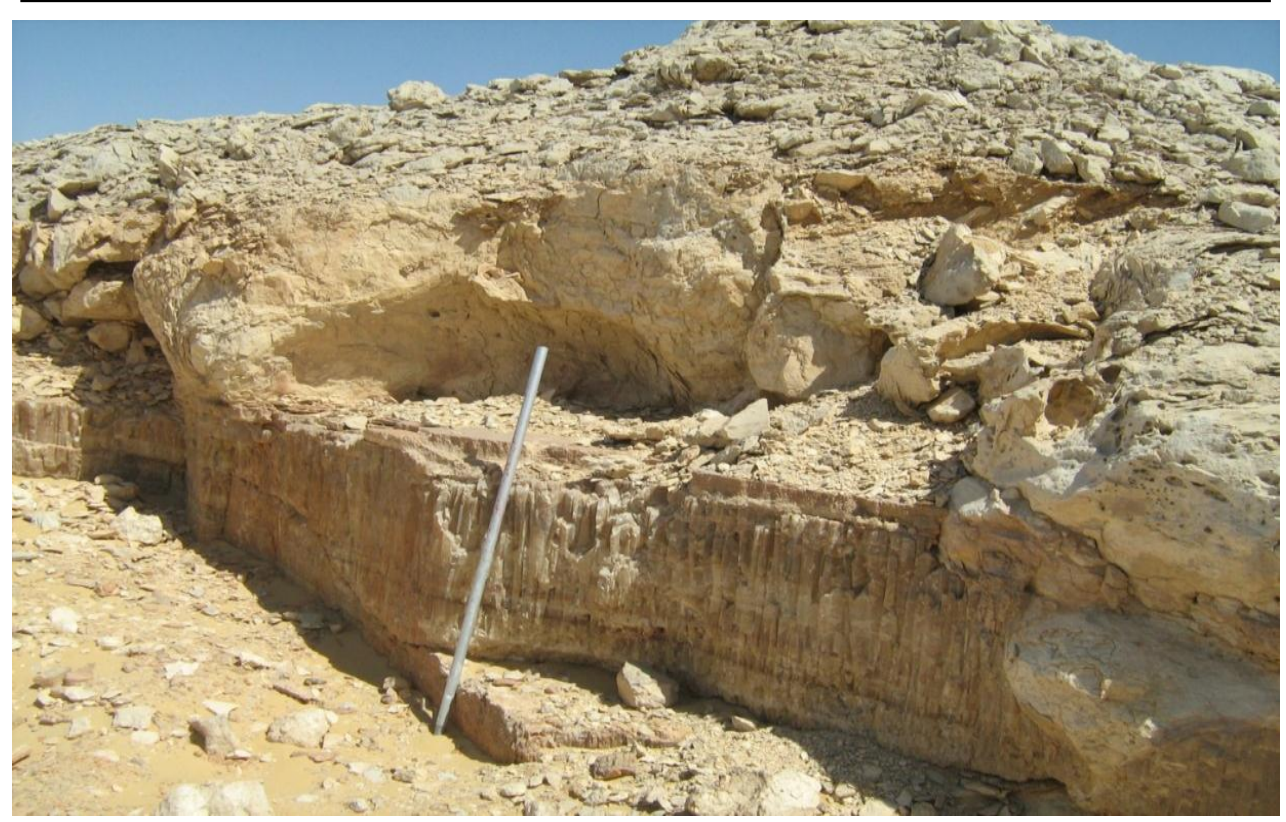

شكل (^) راقات كالسيت تكونت ما بين سطح عدم تطابق داخل تكوين درنكة

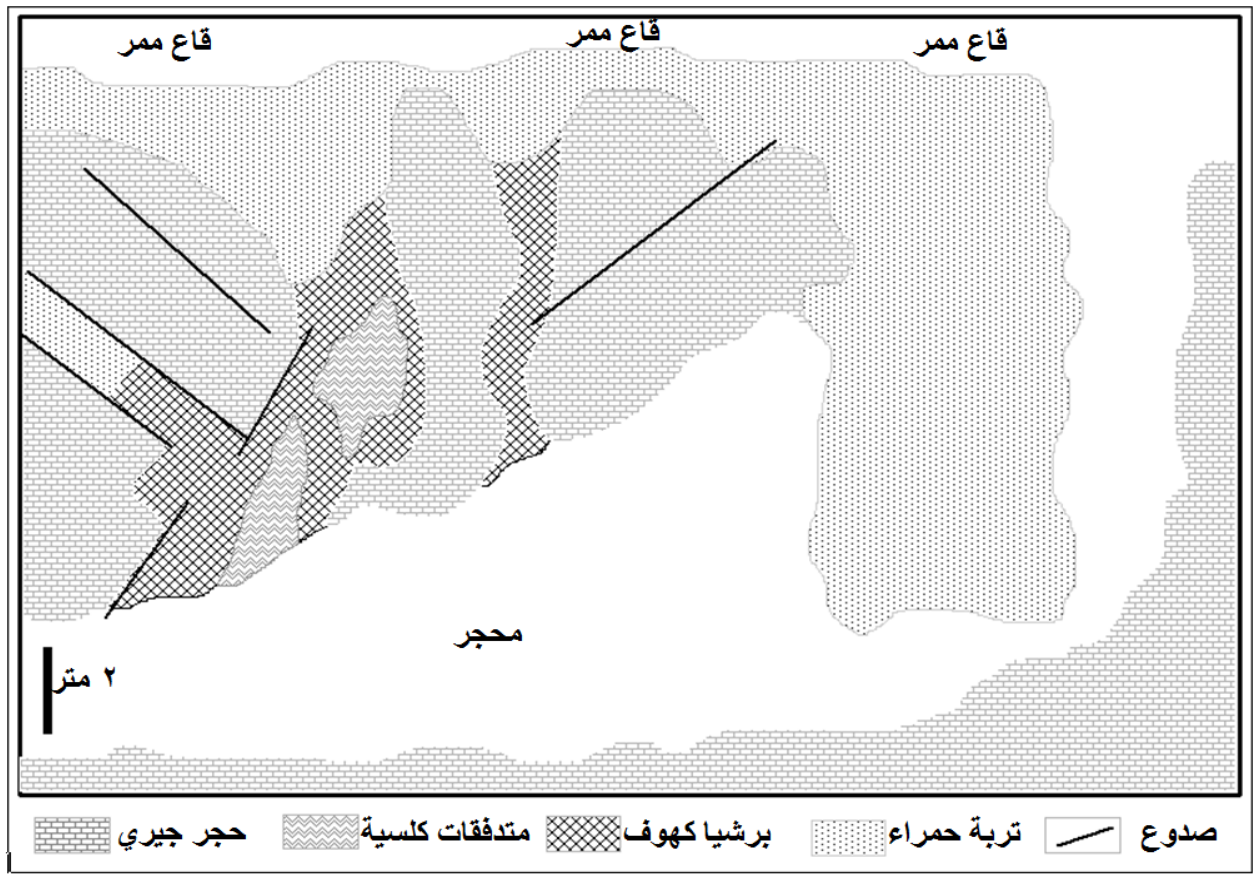

شكل (9) قطاع بأحد المحاجر يوضح المواد المختلفة المكونة لكهـف منهـــار تحت سطحي تم الكثف عنه من خلال أحد المحاجر التي حفرت فــي

$$
\text { قاع أحد الممرات }
$$


"sandy على هذا الخليط اسم برشيا رملية حمر اء (1934) عandford

red breccias" الخارجة. يغطي هذه التزبة أحيانا فرشة حصوية سطحية، ولم يستدل علـى أي

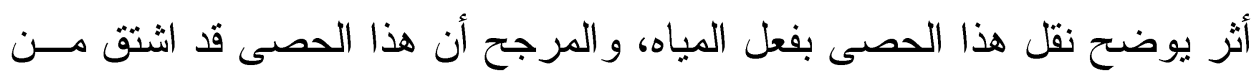
تكويني درنكة والمنيا بنطاق الممرات. جدير بالذكر أنه قد رصد كتل من الحجر الجيري غير منتظمة الثكل مدفونة في التربة الحمر اء، ويتخلل هذه الكتل حفــر إسطو انية ناتجة بفعل الإذابة، تزاوح قطر ها ما بين ب-1 سم وبلغ طولها (Yo)

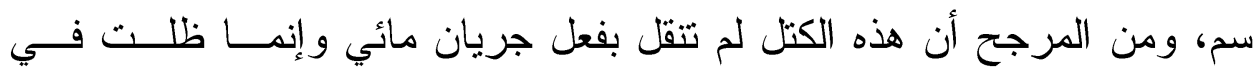
موضعها كنتاج لانهيار ات كهفية أو انهيار دولينات كبيــرة، وأن هــــه الحفــر

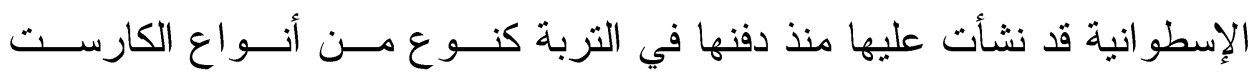
المغطى، وقد استدل على ذلك من خلال الانسيابية و الســطح المصـقول الــذي يميزها، و هي صفات تميز الكارست المغطى بالرو اسب. ترتكز طبقة التربة الحمر اء السابقة على طبقة من الحجر الجيري شديدة التأثز بالإذابة يبلغ سمكها ( • () أمتار، وتعد هذه الطبقة انتقاليــة بــين التربـــة

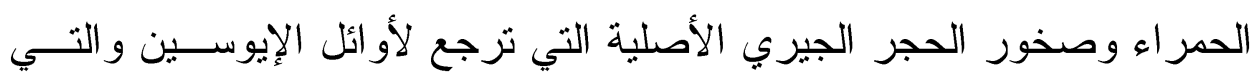
أوضحت عمليات حفر آبار المياه أنها تحوي فجوات كهفية، ويمكن تصنيف أول طبقتين على أنهها جزء من نطاق "قشرة الكارست" Epikarst zone الذي يعرف بأنه نطاق الحجر الجيري المجوى (شكل • (1). تتفق النتائج السابقة مع نتائج المســح السيزمى غير العميق الذي أشـار إلى وجود ثلاثة نطاقات هي: التربة والحجــر الجيري المجوى والحجر الجيري الأصلي، تزاوح سمك نطاق التربة ما بين (r)

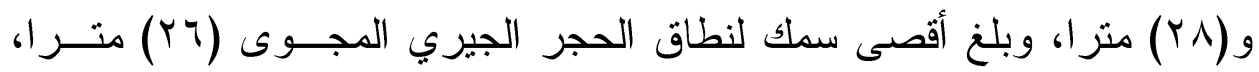
وبشكل عام فإن عمق الصخر الأصلي قد تباين ما بين (9) أمتار إلى (^ץ) متر ا .(Shabaan, 2008) 
أوضحت عملية فحص مظاهر السطح الدقيقة لبعض حبيبات الكـــوارنز

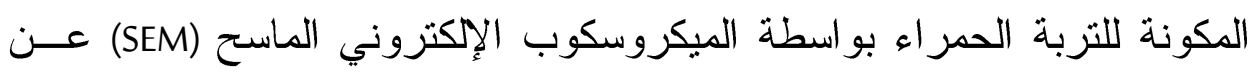
تأثز هذه الحبيبات بعمليات كيميائية وميكانيكية؛ حيث كثفت عن انتشــار حفــر إذابة ومنخفضات عميقة لا يمكن أن تتكون إلا بتأثير التجوية الكيميائية وتحديدا الإذابة، كما ظهرت منخفضات شكل رقم (V) (حرف v بالانجليزية) (شكل (I) ).

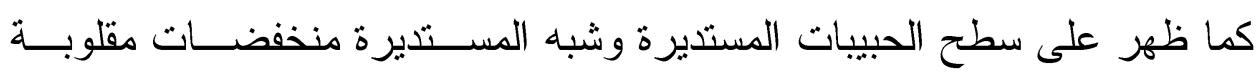

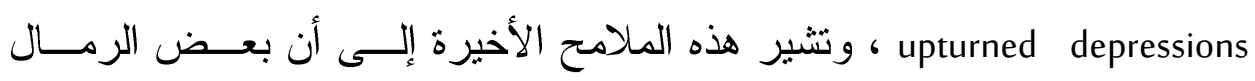

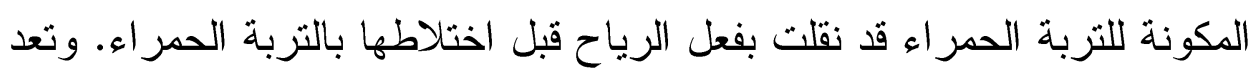

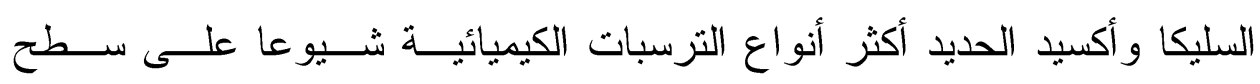

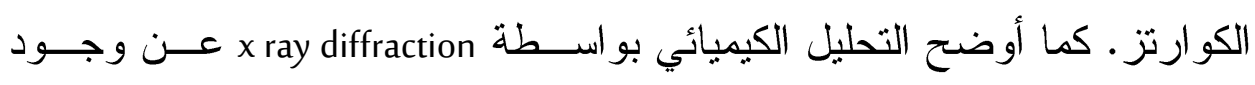

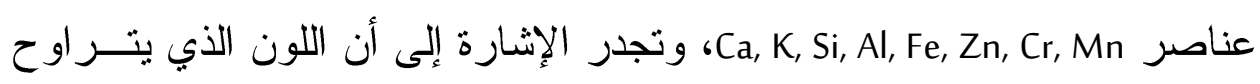
بين الأحمر و البني يرجع إلى وجود أكاسيد حديد (الهيماتيت و الجيوتيت).

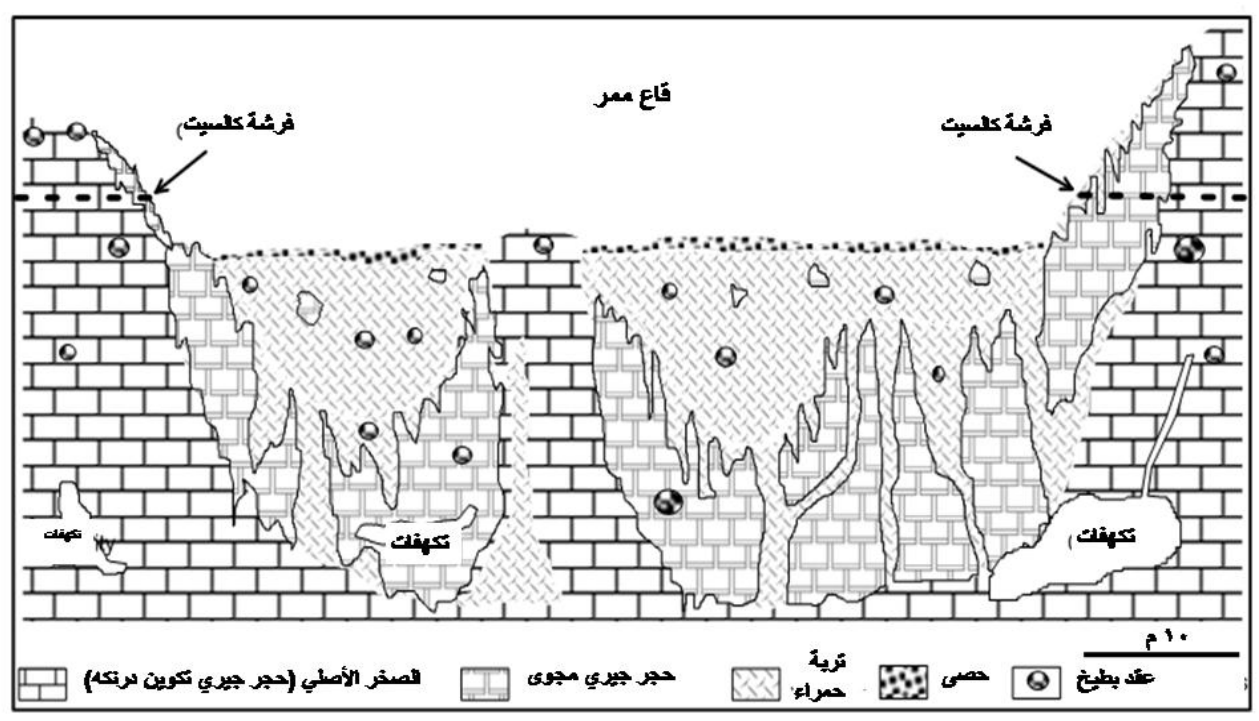

شكل ( • 1) قطاع يمر بأحد الممرات يوضتح الطبقات الثلاثة المختلفة أسـفله، حيـث

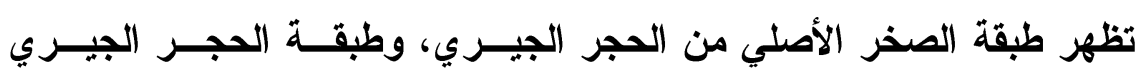

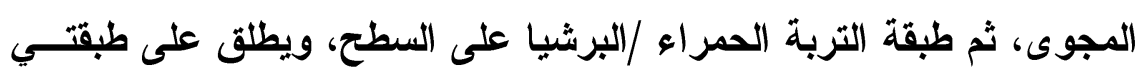
الحجر الجيري المجوى والتربة الحمراء اسم "قشرة الكارست

(المصدر : دراسة ميدانية) 


\section{}

حشو الكهف هو خليط من الرواسب التي تملأ الفراغ الكهفي، وعادة ما

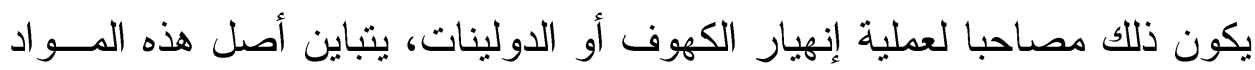

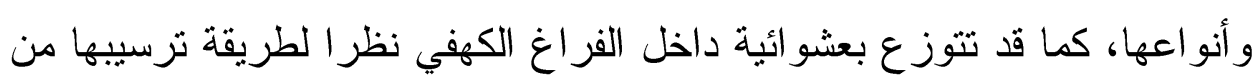

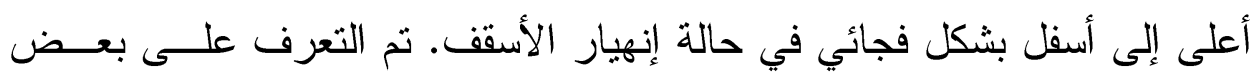

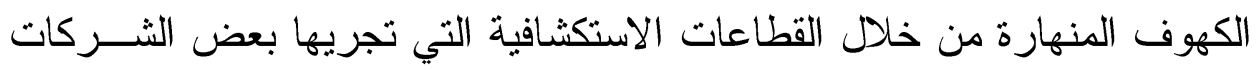

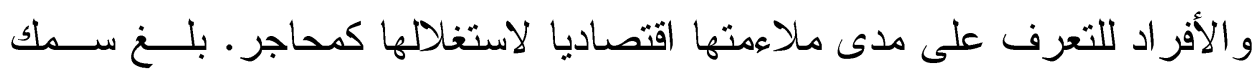

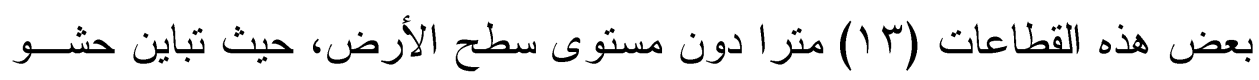

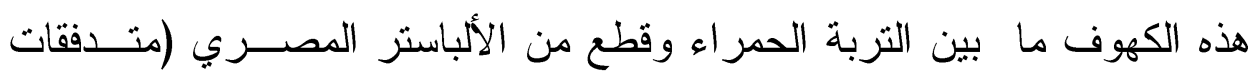
كلسية flowstone) وكتل من الحجر الجيري الأصلي، وبرشيا الكهوف، ويتماسك الكئك

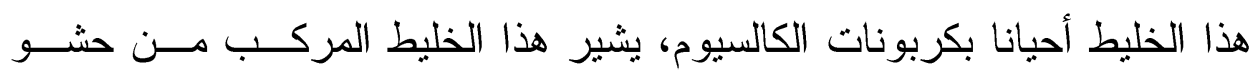
الكهوف إلى تاريخ معقد من تطور الكارست السطحي في نطاق الممرات، حيث يشير الفراغ الكهفي الكبير للكهوف إلى نشاط طويل لعملية الإذابة، كما أن وجود

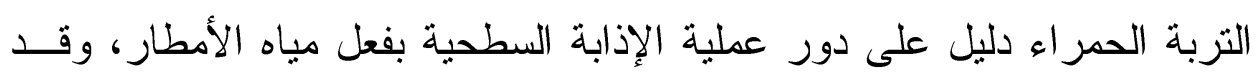
لازم ذلك أو تلاه في مرحلة جديدة ترسيب الكالسيت في شكل متدفقات كلسية أو دولئ

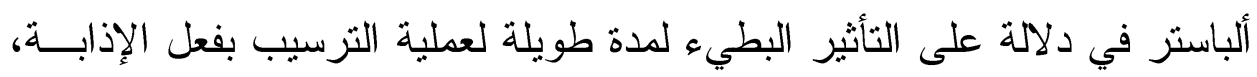
وقد شارك في العمليات السابقة انتقال بعض الرواسب إلى داخل الكهف لتشـــل فر اغه بالكامل، و على هذا فإن حشو الكهوف بالمنطقة كان نتاج عمليتين: الأولى لثى هي الانهيار الكهفي الذي نتج عنه كتل الحجر الجيري التى كانت مكونة لأسقف

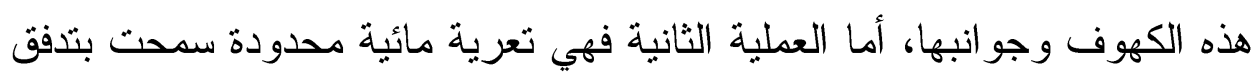
مو اد مختلفة إلى داخل الفراغ الكهفي. وقد تلى العمليتين السابقتين تماسك بعض لهض الخليط بفعل كربونات الكالسيوم مكونا برشيا الكهوف التي تحمل بداخلها فتــات

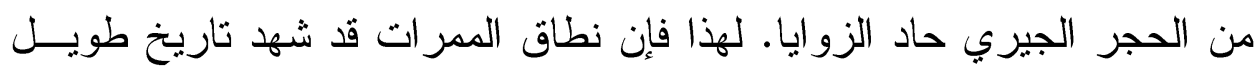
ومعقد من عملية الإذابة و الترسيب الكيميائي و التعرية المائية و عمليـــة انهيــار

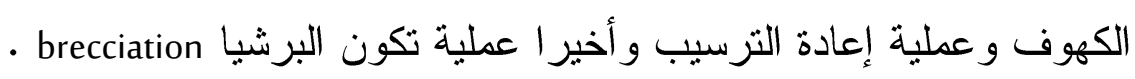




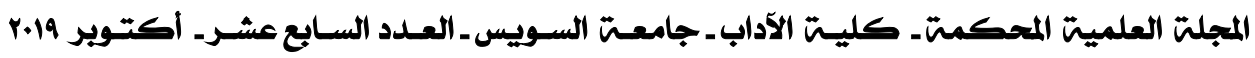




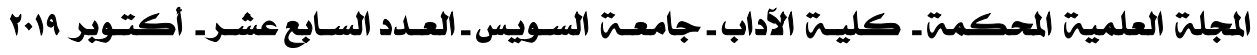
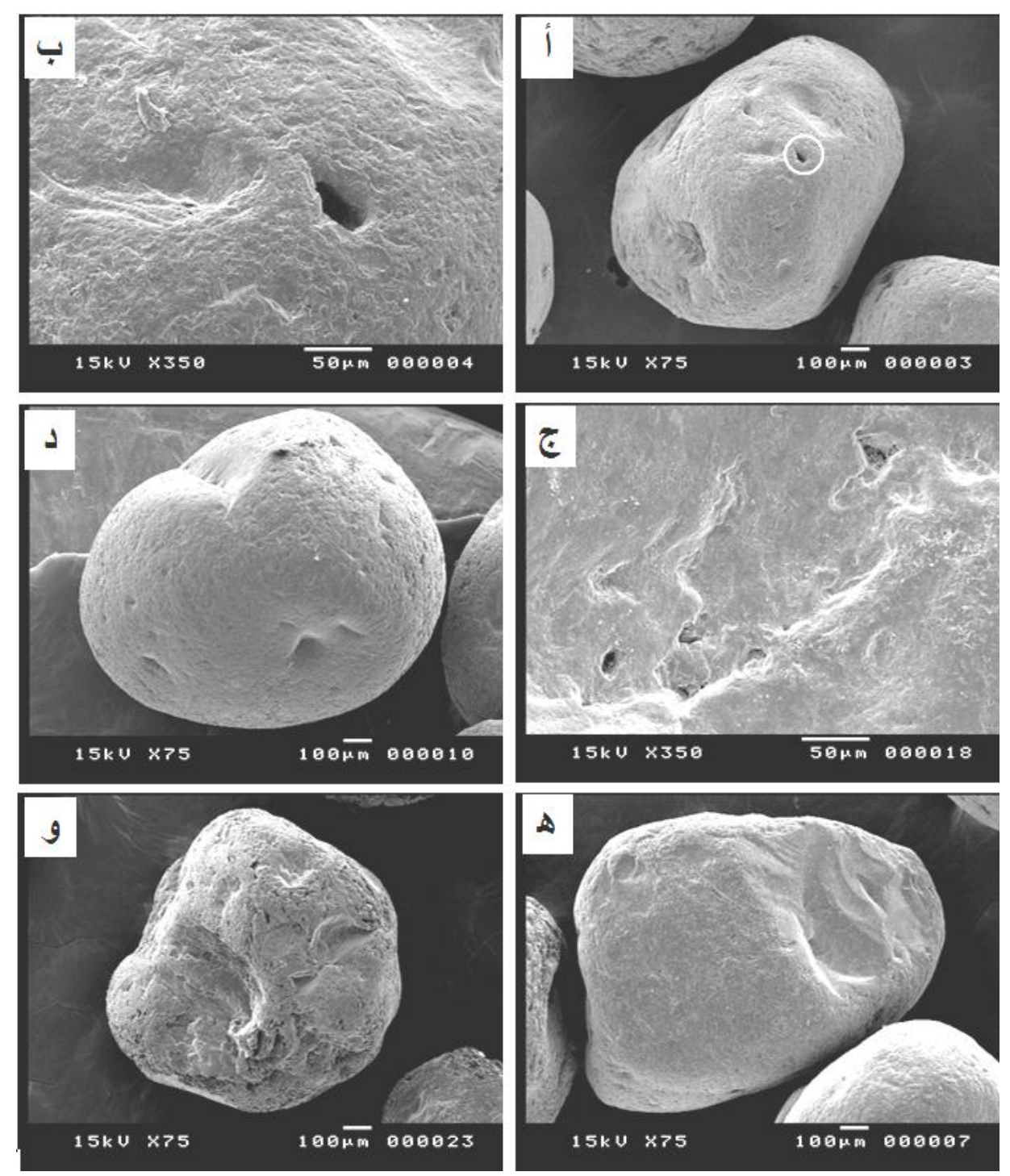

شكل (11) مجموعة من صور الميكروسكوب الاككترونـي الماســـ (SEM) توضــح النسيج السطحي لبعض حبيبات رمال الكوارتز، حيث توضح صوره (أ) حفرة إذابة عميقة مميزة على سطح حبيبة الكوارتز، (ب) صــورة مقربــة لحفــرة الإذابة الموجودة فى صورة ب، (ج) ترسبات كيميائية داخل أحد المنخفضات،

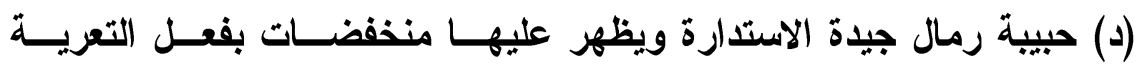

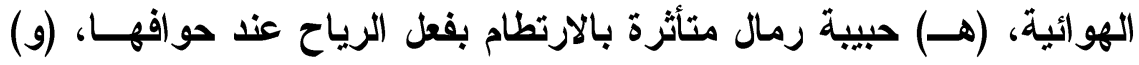

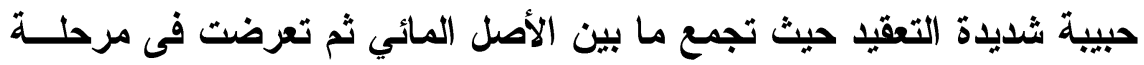

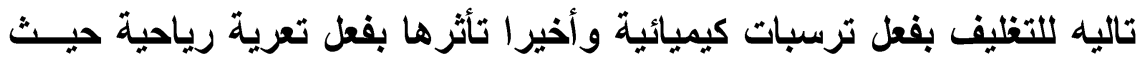
تظهر منخفضات طولية تقطع الترسبات. 


\section{צ-r متبقبات الإذابة (الصوان، عقد البطبخ، النبمولبت):}

يقصد بمتبقيات الإذابة تلك المواد غير القابلة للإذابة، ويمكن حصر هذه

المواد في ثلاثة أنواع هي الصوان وعقد البطيخ السيليكية و النيموليت، وتتفق هذه المو اد جميعها في حقيقة مهمة وهي أنها مو اد تبقت على السطح بعد إذابة الحجر الجيري الذي كان يحويها، و عادة ما تكون هذه المواد موضعية النشأة وتــــبط بالمكان الذي اشتقت منه. كما أن وجود هذه المواد على السطح يؤكد على حقيقة مهمة وهي أن عملية الإذابة التي تحكمت في النشأة هي الإذابة السطحية بفعـل

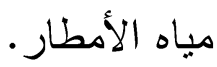

\section{V: الإناقشــــة}

\section{V-V}

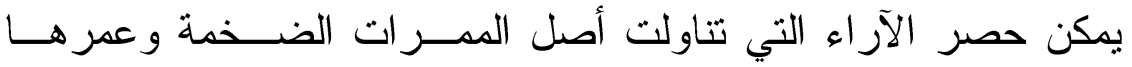
وتطور ها في ثلاثة فرضيات رئيسية: الأولى هي فرضية (2001) Brooks و التـي تزى أن الممرات قد نشأت بشكل رئيسي بفعل تعرية مائية قوية أثثــاء عصــر

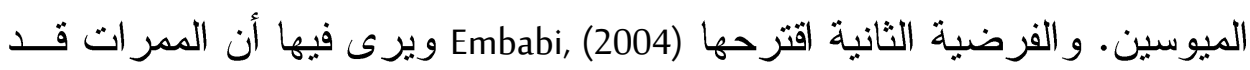
نشأت بفعل عملية الكارست السطحي، وقد سبقها جريان مائي بامتداد نطاقـات ضعف بنيوي خطية، وقد اتفق معه Mostafa, في الأصل الكارستي بفعـلـ مياه الأمطار Epigene karst . أما الفرضية الثالثة فقد اقترحتها در اسة Tewksbury و والتي تزى أن المدرات عبارة عن طيات ســــ (خســف) غيــر تكتونية نتجب بفعل انهيار ات على أعماق كبيرة بفعل مظاهر كارست حرمائيــة مypogene karst التي تفسر أسباب عملية الخسف المؤدية إلى نشأة الممر ات، وكــان مــن هـــهـ

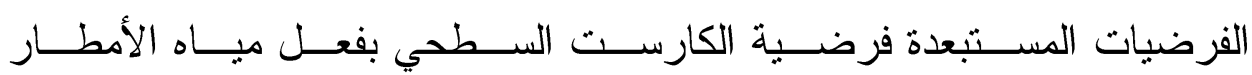
Epigenic/vadose zone karst 


\section{الح- r-V (البرشبيا):}

يعد الحصى المنتشر على سطح هضبة الحجر الجيري فيـــا بــين و ادي

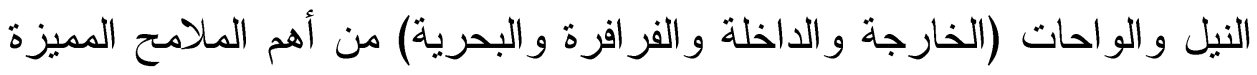

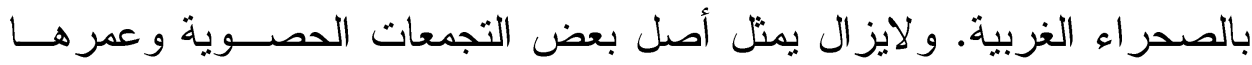
وكذلك العملية أو العمليات المسؤولة عن ترسيبها مجــال نقــاش واســع بــين

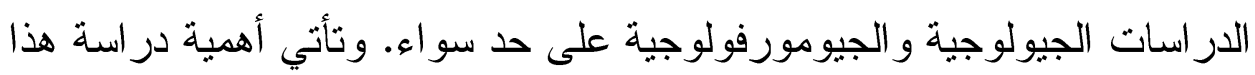

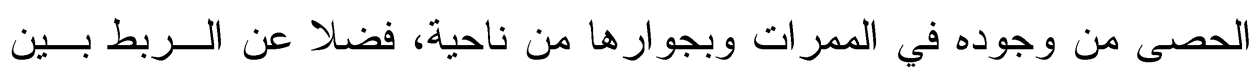

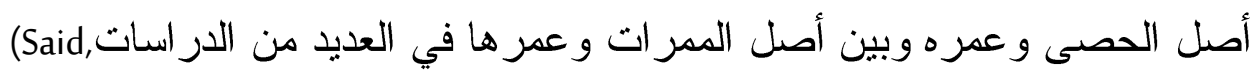
1981, 1983b, and 1990; Klitzch et al., 1987; Brooks, 2001; Mostafa, 2013;

.Tewksbury et al., 2017).

Said (1981, 1983b and 1990) أثارت الخرائط الجيولوجية لمصر عنــــ and Klitszch et al. (1987) وقد أرجعت هذه الدراسات أصل التجمعات الحصوية إلى أنظمة تصريف ضخمة إلى

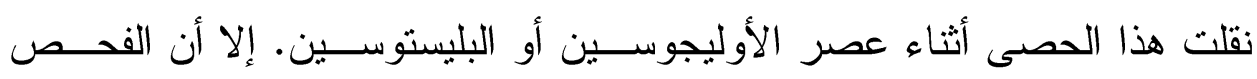

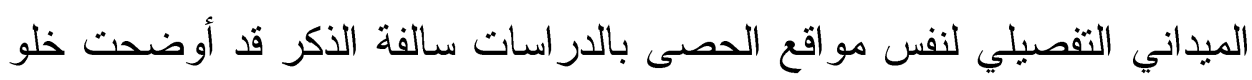

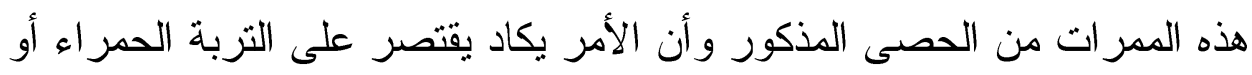

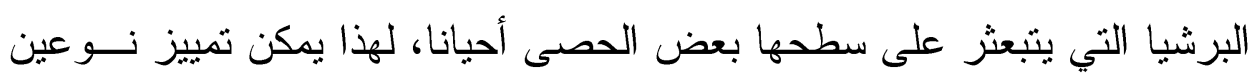

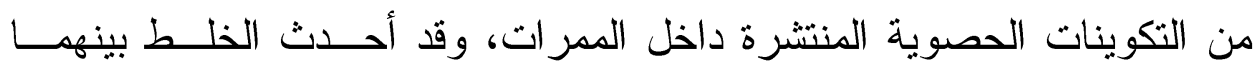

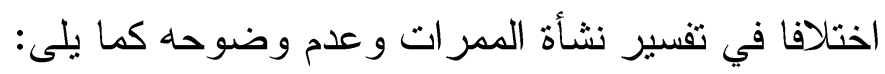

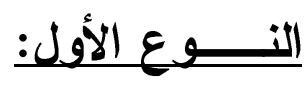

هو التلال الحصوية المنتشرة في حقول منعزلة على سطح هضبة الحجر

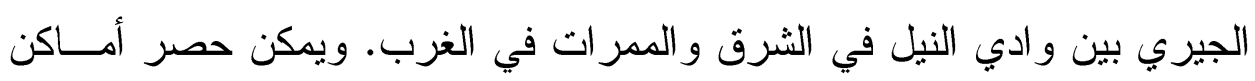


وجود هذا النوع من الحصى في أربعة تجمعات رئيسية على ســطح الهضــبة الجيرية غرب وادي النيل، هذه التجمعات من الجنوب إلى الثمال هـيـي: الأول: نطاق فرشوط - جرجا، و الثاني: نطاق غرب مدينة سو هاج، والثالــــ نطــاق غرب منفلوط، و الر ابع نطاق غرب ديروط (شكل ( ). وقد صنفت تلال الحصى إلى الغرب من نطاق فرشوط-جرجا وكذلك نطاق غرب سوهاج على أنها تكوين

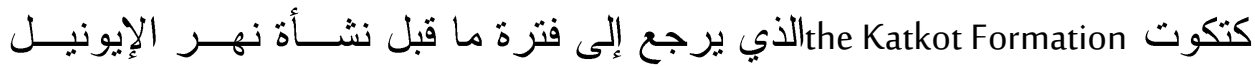
(أو اخر الأوليجوسين- أو ائل الميوسين؟). تستقر هذه التجمعات الحصوية بشكل إس أير منو افق على تكوين درنكة الذي يرجع إلــى أوائـلـل الإيوســين Issawi, and ويعادل تكوين كتكوت تكوين اليتيم (McCauley,1993; Issawi, 2005; Abu Seif, 2015) الذي يرجع إلى مرحلة ما قبل الإيونيل (أي نهر النيل الأول) الذي نشأ في أواخر El-Haddad et al., عصر الميوسين طبقا لدر اسة (2014) يرى(Mostafa أن تلال الحصى غرب أسيوط (غرب منفلوط ومير)

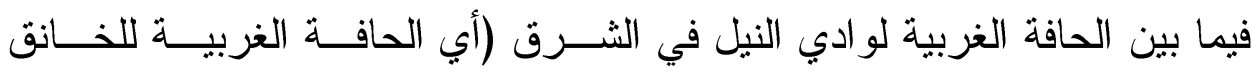
الايونيلى) ونطاق الممرات في الغرب بمثابة "أحد أســـح التعريــة الحصـــوية القديمة" التي تكونت في الفترة من نهاية أوائل الإيوسين حتى الميوسين الأوسط، وقد رجحت الدر اسة أن تلال الحصى قد نشأت كمو اد متبقية نشأت فــي نطــاق "قشرة الكارست" epikarst zone الذي قد يمثل أحد دورات التعرية الكارســتية أو

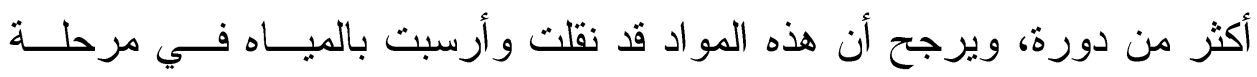
متأخرة. وطبقا للار اسة الحالية فقد أطلق على "سطح التعرية الحصـــوي القــديم" رهـ الذي يعادل "تكوين كتكوت" و"تكوين اليتيم" مصطلحا أكثر دلالة يربط بين فتـرة

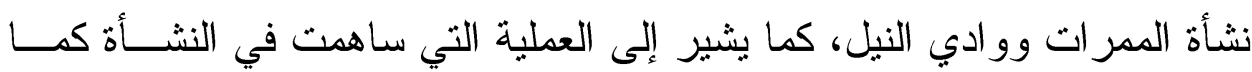
سوف يتضح، هذا المصطلح هو "سطح تعرية ما قبل الأزمسـة الميسـبينية" 
(1) Messenian Erosion Surface" or PMES gravel. المسميات و الأعمار المختلفة لهذا النوع من الحصى في دراسات مختلفة، فضلا عن عمر الممرات.

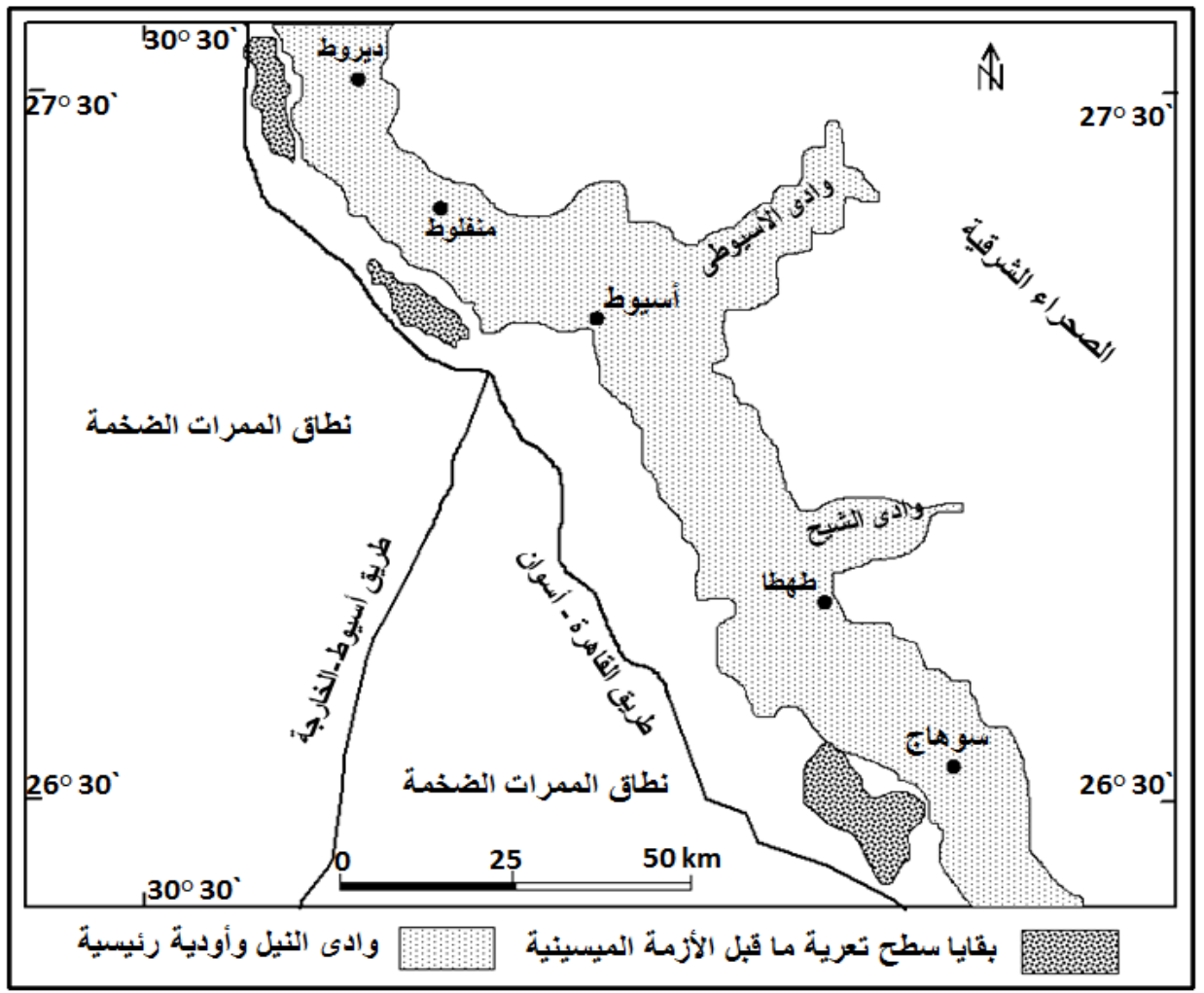

شكل (Y I ) بقايا سطح تعرية ما قبل الأزمة الميسينية

(المصدر: الملاحظات الحقلية ومرئيات جوجل ايرث)

أما عن العلاقة بين التلال الحصوية التي تمثل "سطح تعرية ماقبل الأزمة الميسينية" و الممر ات، فالو اضح على مستوى كل التجمعات الأربعة سالفة الــذكر أن هذه التكوينات لم ترصد داخل الممرات عكس ما ذكر في بعض الدراســات الســابقة (Said, 1981, 1983b, and 1990; Klitzch et al., 1987; Brooks, 2001). وللتوضيح فقد تم دراسة هذه التجمعات إلى الغرب من منفلوط ومير في أسيوط.

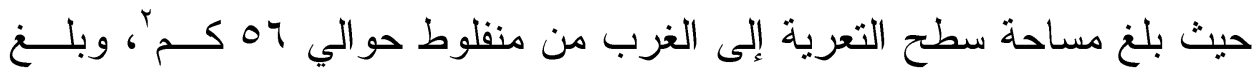


أقصى منسوب لها حو الي (Y)

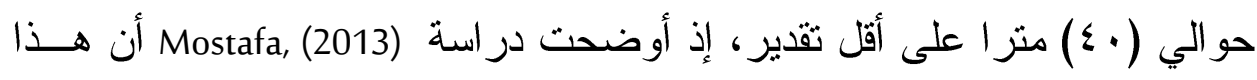
النوع من الرواسب من المتوقع أن يصل منسوبه إلى Or مثر ا حيث رصد ذات الحصى داخل آبار كارستية paleokarst shafts مملو عة بالحصى و الكونجلوميريت وذلك على قمم تلال من الحجر الجيري. أما عــن منســوب قيعــان المـــرات

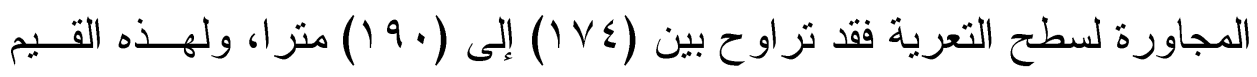
أهمية كبيرة حيث تشير إلى أن منسوب الحصى المنتمي إلى "سطح تعرية ماقبل

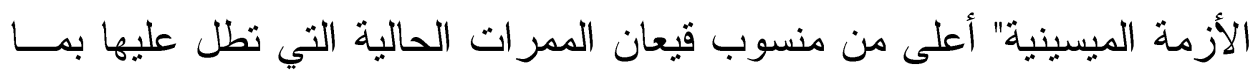

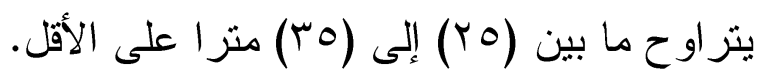

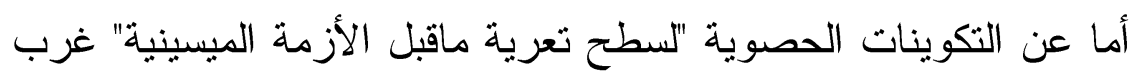

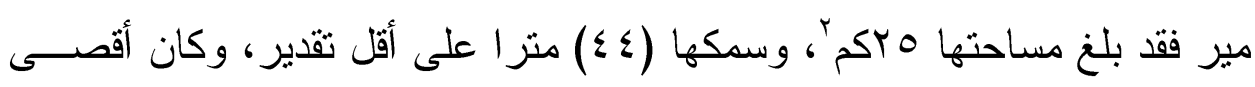
منسوب للحصى حوالي ( IV.) متر ا. أما عن منسوب الممرات فقد تراوح مهـ

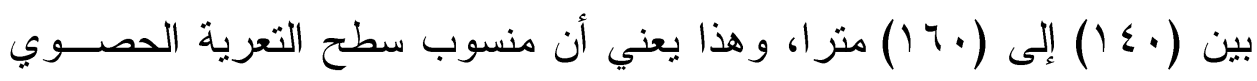
أعلى من منسوب الممرات بما يتر اوح ما بين · ا إلى · ب متر ا غرب مير.

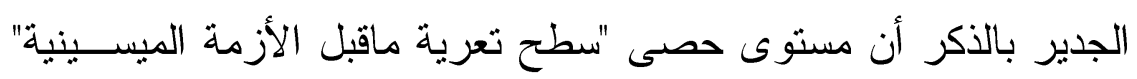
غرب منفلوط وغرب مير قد قطع بواسطة وادي النيل، أي أن الخانق الايونيلى الذي نشأ أو اخر الميوسين أحدث من الحصى المكون لسطح التعرية. وتتفق نتيجة

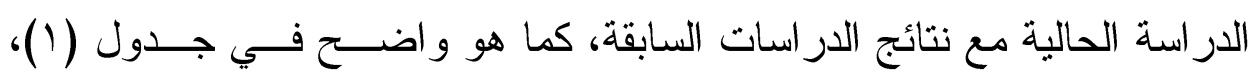
بمعنى أن عمر هذا النوع من الحصى المكون لسطح التعرية أقــدم مــن نشــأة الخانق الإيونيلى أواخر الميوسين. وترجح الدراسة الحالية نشأة سطح التعريـــة خلال الفترة من نهاية أو ائل الإيوسين حتى أو اسط الميوسين.

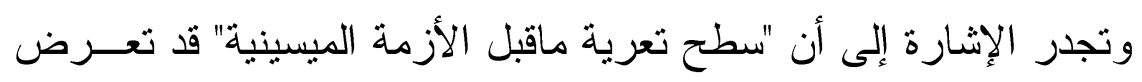
في مرحلة أحدث لتعرية مائية قطعت سطحه وذلك من خلال شبكة الأودية التي جرت من الغرب باتجاه وادي النيل. ويرجح أن عمر هذه الثبكة يرجـع إلـى 
عصر البليستوسين وذلك اعتمادا على خلو مصبات هذه الأودية مــن رواســب أبـ أبـات

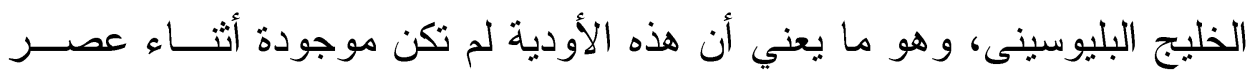
البليوسين.

من ناحية أخرى، فإن وجود "سطح تعرية ماقبل الأزمة الميسينية" علـى

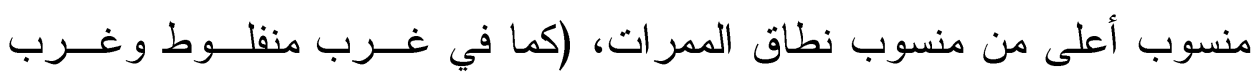
ديروط) يشير إلى أن هذه الممرات لم تكن موجودة أثناء ترسيب حصى ســطح التعرية، بمعنى آخر: فإن هذه الممرات قد نشأت أثناء أو بعد نهاية الميوســين؛ لهذا فإن المرجح بشكل قوي أن سطح التعرية أقدم من الممرات. تختلف النتيجة الأخيرة بالدر اسة الحالية مع ما توصــلت إليـــه در اســـة Tewksbury et al. (2017) هذه التكوينات الحصوية (تكوين كتكوت) ترتكز بشكل غير متو افق علـى هــــه الممرات (طيات السحب غير التكتونية)؛ ولهذا استخلت على أن هـــه المـــرات أقدم من تكوين كتكوت. إلا أن النتيجة الأخيرة قد تكون غير مقبوله لعدة أسباب: أو لا: أن ارتكاز تكوين كتكوت الحصوي على الممرات غير شائع؛ حيث يظهر في عدد محدود جدا من الممرات التي تتركز بالجنوب إلى الغرب مباشرة مسن

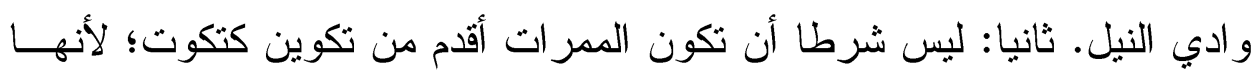
Tewksbury et al. أسفل منه، فطبقا لفرضية الخسف غير التكتونية التي اقترحتها

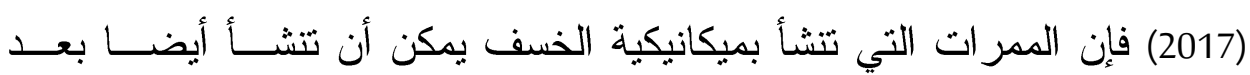
تزسيب الحصى. ثالثا: أما عن تفسير تأثر هذه الممرات المدفونة بالتعرية كمــا

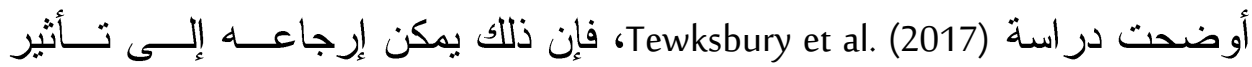

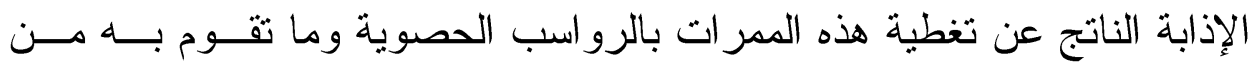

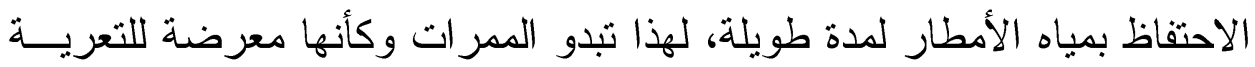
إلا أن الو اقع قد يكون بفعل تأثر ها بالإذابة الناتجة عن التغطية بالحصى، أو مــــا يسمى بالكارست المغطى covered karst. 


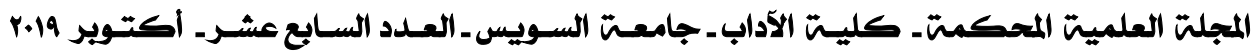

جدول (1) عمر حصى"سطح تعرية ما قبل الأزمة الميسينية" والممرات الضخمة فى الار اسات المختلفة.

\begin{tabular}{|c|c|c|}
\hline عمر حصى"سطح تعرية ما قبل الأزمة & عمر الممرات & الارخات المختلة \\
\hline تلال الحصى" يرجح أوليجوسينى؟" & أنظمة تصريف يرجح & Said (1983) \\
\hline حصى أوليجوسيني إلى بليستوسين & 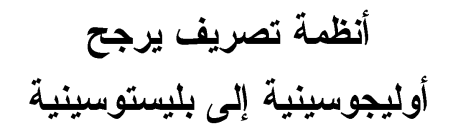 & Klitszch (1987) \\
\hline تكوين كتكوت "أوليجوسينى" & - & $\begin{array}{l}\text { Issawi et al. } \\
\text { (1999) }\end{array}$ \\
\hline ماقبل الميوسين الأوسط (يرجح نهاية & 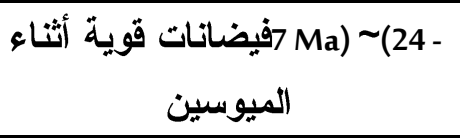 & Brookes (2001) \\
\hline نهاية أوائل الإيوسين - نهاية الميوسين & - & Mostafa (2013) \\
\hline أو ائل الميوسين & - & $\begin{array}{l}\text { Mahran et al. } \\
\text { (2013) }\end{array}$ \\
\hline تكوين اليتيم، مرحلة ما قبل الإيونيل & - & $\begin{array}{c}\text { El-Haddad et al. } \\
\text { (2014) }\end{array}$ \\
\hline 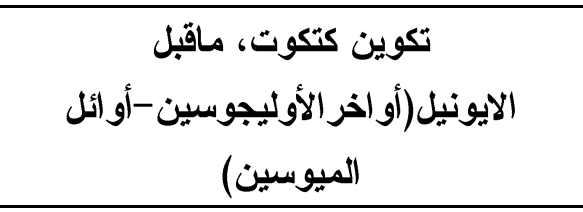 & - & Abu Seif (2015) \\
\hline تكوين كتكوت (أوليجوسين - أوائل & 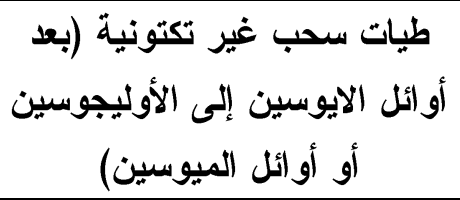 & $\begin{array}{c}\text { Tewksbury et al. } \\
\text { (2017) }\end{array}$ \\
\hline تكوين كتكوت (أوليجوسين-أوائل & 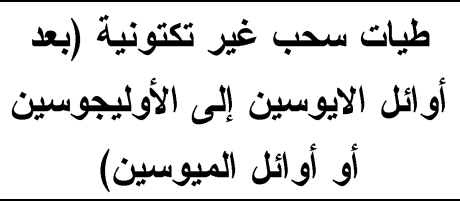 & $\begin{array}{c}\text { Tarabees et al. } \\
\text { (2017) }\end{array}$ \\
\hline 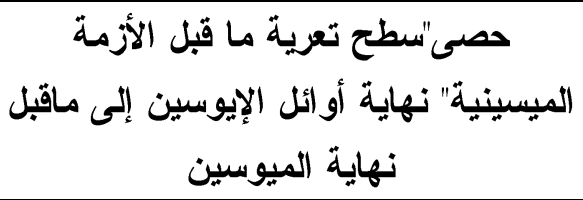 & الميوسين حتى أوائل البليوسين) (البداية) & الار اسة الحالية \\
\hline
\end{tabular}


يشير وجود حصى "سطح تعرية ماقبل الأزمة الميسينية" على منســوب

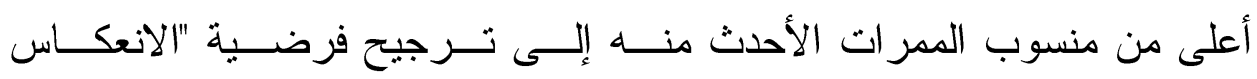
الطبو غر افي" بين مستوى التعرية وسطح منطقة الممرات، بمعنــى أنــهـ أثتـــاء ترسيب هذا الحصى كانت منطقة الممرات أعلى منسوبا من منــاطق ترســـبـ الحصى التي يرجح أنه أرسب في أحو اض كبيرة، وقد أثنارت بعض الدراســات إلى وجود هذا الحصى في أحواض بنيوية كما هو الحال غرب مدينــة ســـوهاج وغرب نطاق فرشوط- جرجــا (El-Haddad et al. 2014; Abu Seif, 2015). الجــدير

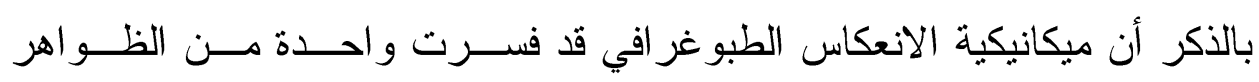

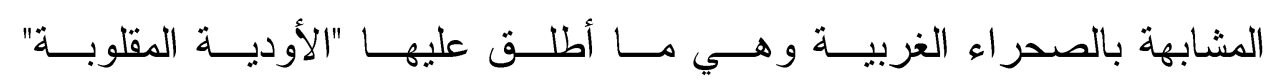
.(Embabi, 2004; Zaki and Giegengack, 2016$)$ Inverted valleys و الخلاصـة أن حصى سطح التعرية غيــر موجــود داخـلـل المـــرات، ويقتصر وجوده على خارج حدود الممرات فيما بين الممرات ووادي النيل، وأن هذا الحصى قد أرسب في منطقة منخفضة طبو غر افيا بالمقارنة بمنسوب نطــاق الممرات الذي كان أكثر ارتفاعا وبالتالي لم تكن الممرات موجودة أثناء ترسيب الحصى الذي أرسب قبل نهاية الميوسين، أي قبل الأزمـــة الميســـينية، ونظـــرا لصلابة التكوينات الحصوية مقارنة بالصخور الجيرية المكونة لنطاق الممـرات ات اتهرئ و التي تتسم بسهولة تأثر ها بعو امل التجوية و التعرية، حدث انعكاس طبـــوغر افي نتج عنه بقاء التكوينات الحصوية على ذات منسوبها تقريبا وحــدوث تخفــيض لسطح الحجر الجيري الذي نشأ فيه بعد ذلك الممرات(شكل ع ().

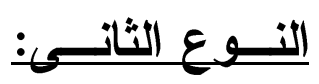

يتمثل هذا النوع من التكوينات في التربة الحمر اء و البرشيا المنتشرة على قيعان الممرات ويغطيى سطحها فرشة حصوية، أدى انتشار الحصى على سطح التربة الحمر اء و البرشيا إلى تصنيف هذه التكوينات في بعض الدر اســات علـى 
أنها تكوينات حصوية فيضية أوليجوسينية إلى بليستوسينية، وهو الأمر الذي ظهر

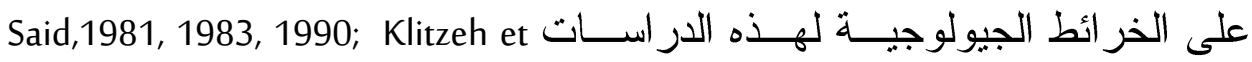
(al.1987)، و التي تعادل تكوين "سطح تعرية ماقبل الأزمة الميسينية" طبقا للار اسة الحالية (أو تكوين كتكوت، أو اليتيم، أو وحدة ما قبل الإيونيل طبقـــا للار اســات (السابقة).

أما عن تصنيف التربة الحمر اء على أنها تجمعات حصوية في خــرائط الدراسات السابقة، فمن المرجح أن ذلك يرجع إلى ثلاثة أسباب: الأول هـــو أن

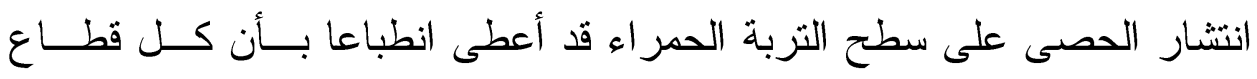
الرو اسب من الحصى، ويفسر (2004) Embabi, سبب تزكز الحصى على ســطح التربة الحمر اء إلى فعل الرياح التي أز الت الرواسب الناعمة ونزكـــ الحصـى على السطح.

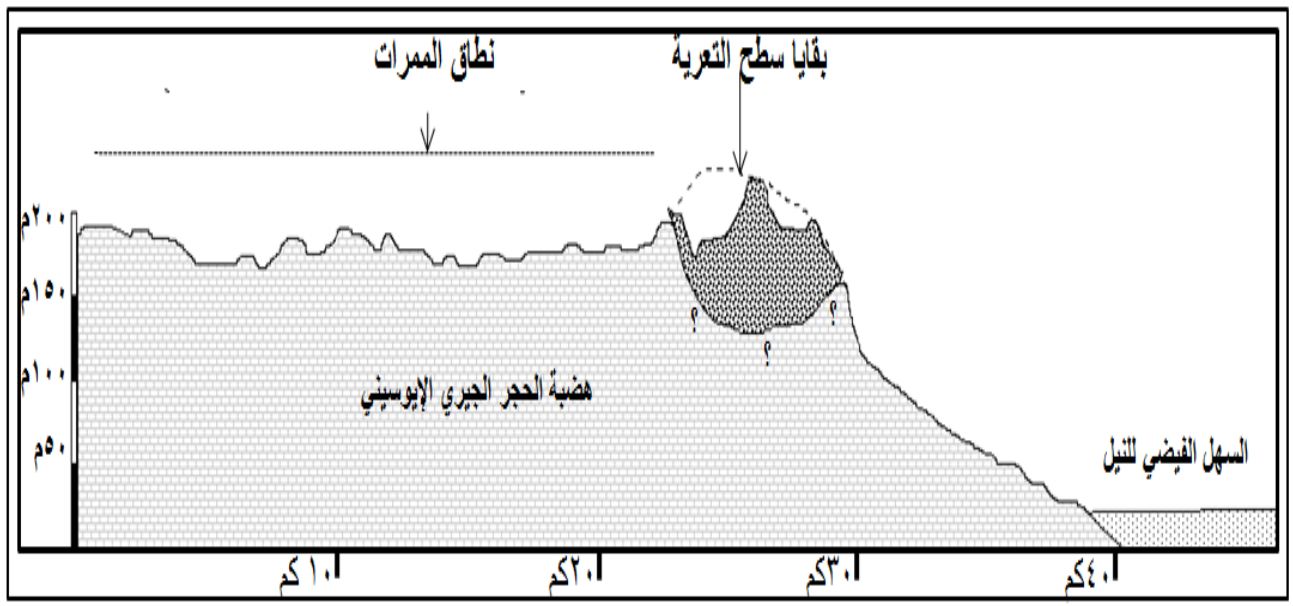

شكل (ب I) العلاقة بين منسوب سطح تعرية ما قبل الأزمة الميسينية (الأعلـىى منسوبا) ومنسوب سطح الممرات (الأقل منسوبا)، ويرجح حـدوث

انعكاس طبوغر افي أدى إلى هذا الوضع

(المصدر: الملاحظات الحقلية ومرئيات جوجل ايرث) 
أما السبب الثاني فيرجع إلى افتقاد الخرائط الجيولوجية فــي الدراســات السابقة إلى الفحص الحقلي لنطاق الممرات (List et al, 1990). ويرجـع الســبـ الثالث إلى تشابه الدرجة اللونية بين الفرشة الحصوية على سطح التربة الحمر اء و تللك الخاصة بحصى سطح التعرية الموجود بين الممرات ووادي النيل وذلـــك على المرئيات الفضائية التي كانت متاحة حينئذ. و الخلاصة أن التكوينات الحصوية التي تتنمى إلى "سطح تعرية ماقبــلـل الأزمة الميسينية" لم تزصد داخل نطاق الممرات، و اقتصرت فقط على الثــريط

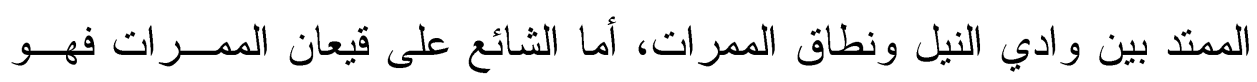
رواسب التزبة الحمر اءو البرشيا التي يغطي سطحها فرشة حصوية.

\section{V-V قنو ات نهرية قوي أو جريان غطائي):}

تشير الخصائص المورفولوجية للممرات إلى أن أغلبهــا عبــارة عـن منخفضات مغلقة إلى شبه مغلقة،أي محاطة بحو اف من ثلاثة اتجاهات. لهذا فإن هذه السمة لا تتفق مع فرضية الجريان المائي القوي أو حتى الجريان الغطــئي

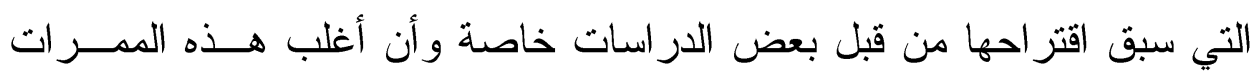
مغلق من جهة الجنوب، الجدير بالذكر أن هذا الاتجاه الجنوبي كان يمثل مصدر

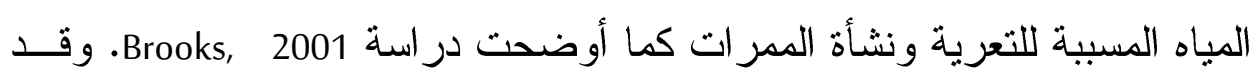
انعكس شكل الممر ات كمنخفضات مغلقة أو شبه مغلقة علـى نمـــ تصــريف

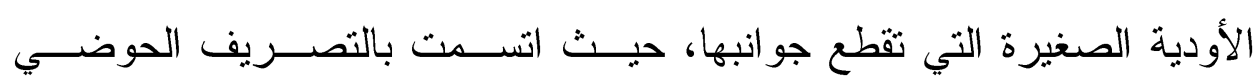
(المركزي) الذي نتج عنه بعض البرك المائية عند أخفض الأجزاء على قيعـان الممرات، كما أثر ذلك بدوره على خصائص الإرسابات الموجودة على قيعـان الممرات، ومع جفاف هذه البرك تظهر تشققات طينية قو امها رو اسب لومية. 
يضاف لما سبق أن إعادة تصنيف الرواسب الرئيسية الموجــودة داخـلـل قيعان الممرات على أنها تربة حمر اء وبرشيا، وليس كما كان يعتقد أنهــا بقايــا أنظمة مائية ضخمة أثناء الأوليجوسين حتى البليستوسين "سطح تعريـــة ماقبـلـل الأزمة الميسينية"، يضعف بشكل كبير الأساس الذي اعتمــدت عليــه فرضـــية الجريان المائي كعملية رئيسية متحكمة في نشأة الممرات.

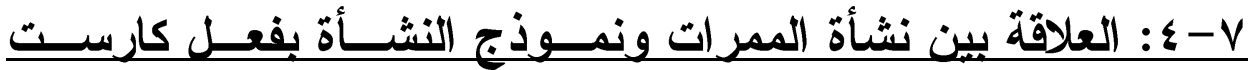

\section{المحالبل الحرمائبة:}

أوضحت در اسة Tewksbury et al. (2017) أن الممرات ليست أشكال ناتجة عن عمليات التعرية و إنما هي عبارة عن طيات مقعرة ناتجة عن عملية ســب (خسف) غير تكتونية، وقد أوضحت الدراسة أن الميكانيكية المسئولة عـن هــــا

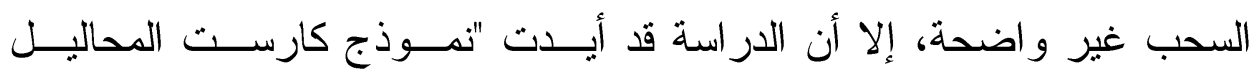
الحرمائية"، وبمعنى آخر: فقد فسرت سبب نشأة الطيات المقعرة غير التكتونيــة إلى إذابة تمت على أعماق كبيرة من السطح بفعل المحاليل الساخنة المتدفقة من باطن الأرض، و التي أحدثت بدور ها كهوفا انهارت وسحبت ما فوقهـا مسـبـية خسف سطحي كون طيات لا ترجع لحركات أرضية. إن قبول "نموذج كارست المحاليل الحرمائية" لتفسير نشأة الممرات قد يكون غير مرضى خاصة فى ضوء الاكتشافات الحديثة لطبيعة هذا النوع من الكارست التى تم تناولها إلى الثرق من نطاق المدرات، وتحديدا على الجانــب الغربــي

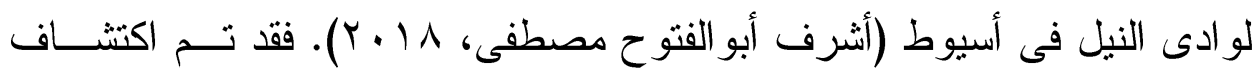
العديد دن كهوف المحاليل الحرمائية التى تحتوى على أغلب الدلائل التى تشــير إلى أصلها، أو ما أصطلح على تسميته "التركيبة المورفولوجية للتدفق المتصاعد" Klimchock, et al., (2000) and طبقا لدر اســتى "morphological suite of rising flow" Klimchock, (2007) وقد شملت هذه التركيبة المكونات الثلاثة الرئيسـية وهــي: 
المدخلات، و الممرات الرئيسية، و المخرجات أو المنافس. وقد تبين أن هذا النمط من الكارست يوجد دون مستوى سطح الهضبة على عمق يتر اوح ما بـين إلى •0 ام، وقد رجحت الدراسة أن عمر هذا النوع من الكهوف قد يرجع إلـى الفترة من الأوليجوسين إلى أوائل الميوسين، حيث شهدت مصر خلال هذه الفترة

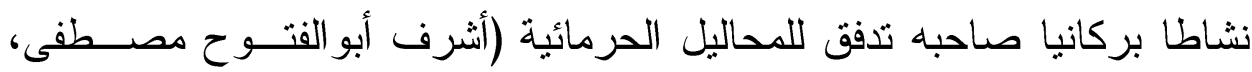
$\cdot(r \cdot) \wedge$ ويمكن حصر أهم الانتقادات التي يمكن أن توجه إلى "نموذج كارســ المحاليل الحرمائية" في تفسيره لنشأة الممرات فيما يلي: - تقع كهوف المحاليل الحرمائية غرب أسيوط على عمق يتز اوح ما بـين إلى لم ام وهو ما يختلف مع ما افترضته دراسة Tewksbury et al. (2017) من

$$
\text { وجود هذا النوع على أعماق كبيرة. }
$$

- اتسم سطح الهضبة الموجود أعلى هذه الكهوف بعدم وجود أي أثــر لطيــات

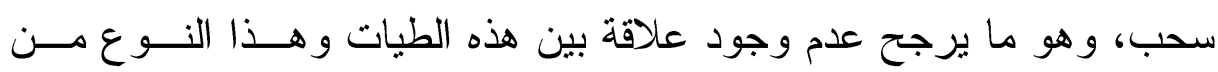
الكارست خاصة في ظل وجوده على أعماق ليست كبيرة كما كان متوقعا. - تشير الملامح المورفولوجية لهذا النوع من الكهوف إلى أن أبعاده محـدودة،

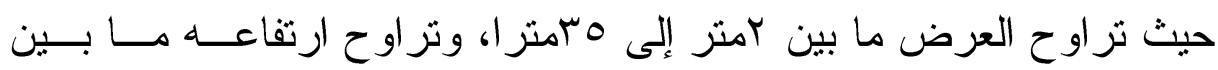
هأمتار إلى الىنرا، كما لم يستدل على أي انهيار كامل بالكهوف الموجودة،

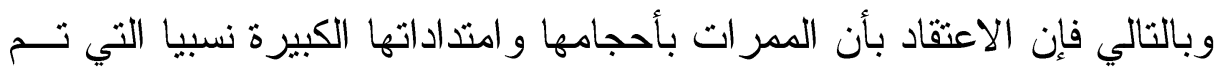
مناقشتها هي نتاج انهيار منل هذا النوع من الكهوف، قد يكون غير مقبول. - يختلف نمط الكهوف و اتجهاها ومنسوبها بشكل كبير، وهو ما جعل هذا النوع من الكهوف يتسم بالطبيعة المعقدة من الناحية المورفولوجية، وتختلـــ هـــه الصفة مع الشكل شبه المنتظم للممرات التي يغلب عليهـــا الاتجــاه الثــــالي

$$
\text { الغربي - الجنوبي الشرقي. }
$$


- تشير الرواسب التي تم در استها في الكهوف المنهارة التي رصدت أسفل قـاع

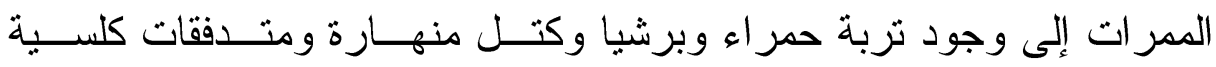
(الباستر) وحصى، و الواضح أن كل هذه المواد نرجح نأثر الممرات بعمليات

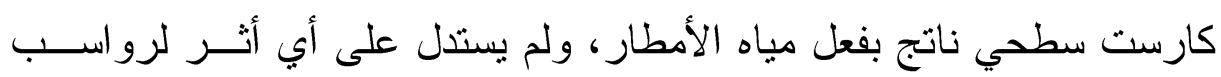
تتنمي لكارست المحاليل الحرمائية.

- من المرجح عدم وجود علاقة بين الخزان الجوفي الذي يتراوح عمقه ما بــين

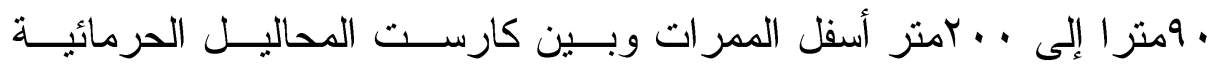
كالموجودة غربي وادي النيل و التي يتر اوح عمقها ما بين هومنز او . . (متر؛ حيث تخلو كهوف هذا النوع من أي وجود للمياه الجوفية. لهذا يرجح أن خزان

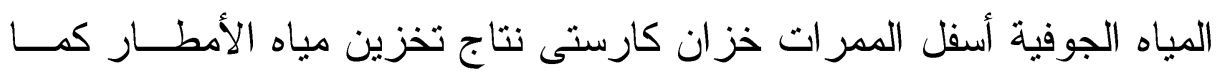
Abou Heleika and Niesner, ) أشارت بعض الدر اسات غرب المنيا وبني سويف 2009; El Kashouty, 2013 وليس له علاقة بكهوف المحاليل المتدفقة من أسفل. - لم تشر الرواسب التي تم استخر اجها أثناء حفر آبار المياه في قيعان الممرات إلى أي أثز للرواسب التي تنتمي لكارست المحاليل الحرمائية. و الخلاصة أنه ليس هناك علاقة ارتباط بين الممرات التي نشأت عن طريق السحب أو الخسف وخصائص كارست المحاليل الحرمائية المكتشفة حديثا إلـى الشرق من نطاق الممرات. لهذا فإن هناك ضرورة للبحث عن ميكانيكية بديلـــة للنشأة يمكن من خلالها تفسير ظهور طيات السحب المقعرة المكونة لعدد كبيـر من الممرات.

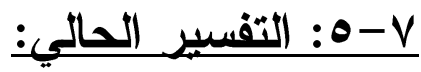

يمكن حصر آراء النشأة الخاصة بظاهرة الممرات في ثلاث فرضــيات رئيسية: ترى الفرضية الأولى أن التعرية المائية من خــلال فيضــانات قويــة (Brookes, 2001). أما الفرضية الثانية فتؤيد عملية الكارست السطحي بفعل ميــاه 
الأمطار Mostafa, 2012) بامتداد صدو ع بنيوية epigenic karst أو كعمليــة تلــت جريان سطحي (Embabi, 2004). وترى الفرضية الثالثة أن هذه الممرات عبــارة عن طيات مقعرة لم تكن ناتجة بفعل عو امل تكتونية و إنما بفعل عملية سحب أو وري خسف بفحل انهيار ات كارستية تمت على أعماق كبيرة بفعل المحاليل الحرمائية. وقد استبعدت الفرضية الأخيرة أي دور للكارســت الســحي . Tewksbury et al .2017; Tarabees et al. 2017) أثبتت نتائج الفحص المبدانى التفصيلي للار اسة الحالية أن رواسب قيعان الممر ات تتكون بشكل رئيسي من التربة الحمر اءو البرشيا التى تشـتقر بشـــل متوافق على الحجر الجيري المجوى المكون للصخور السطحية بالمنطقة، وتتفق (Sandford, 1934; Embabi, هذه النتائج مع ملاحظات حقلية فى در اســات ســابقة 2004 Mostafa 2013، كما تتفق مع نتائج المسح السيزمى التى تزى بوجود سمك من التزبة يصل عشرات الأمتار على قاع أحد الممرات (Shabaan, 2008). الجدير

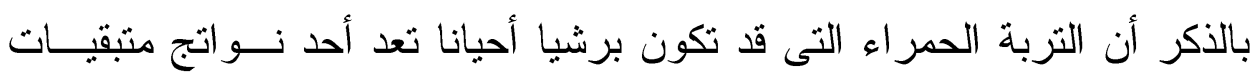
عملية الإذابة السطحية (Embabi, 2004; Mostafa 2013). من ناحية أخرى فقد أكد انتشار حفر الإذابة العميقة على أسطح حبيبات الكوارنز المكونة للتربة الحمراء على دور التأثير القوى لعملية الإذابة السطحية كأحد العمليات الرئيسية المــؤثرة فى تشكيل سطح المنطقة. ومن المرجح أن تكوينات التربة الحمر اء والبرشيا قد تعرضت لإعادة النقل بفعل المياه الجارية لمسافة قصيرة فى مرحلة تالية -Caton) Thompson \& Gardener, 1932 and Embabi, 2004, Mostafa, 2013) ذللك من خلال فتات الحجر الجيري حاد الزوايا المختلط بالتربة الحمر اء، ومــن المرجح أن يكون ذلك من خلال مجارى الأودية الصغيرة المتجهة من جوانــب.

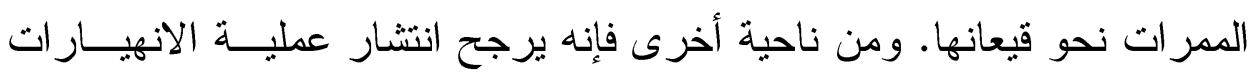
الكهفية أو انهيار دولينات (منخفضات كارستية) كانت موجودة مكان المـــرات، 
وقد استدل عليها من خلال كتل الحجر الجيري المدفونة بالتربة الحمراء (شــكل

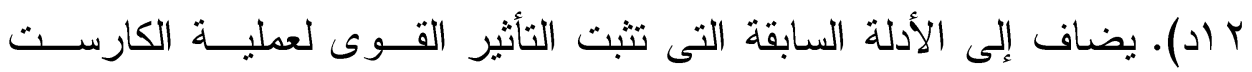
السطحى ما تم رصده من انتشار لحقول البطيخ المصقول سواء علــى قيعـان الممرات أو على جو انبها، بعض هذه العقد منفصلة على السطح و البعض الآخر

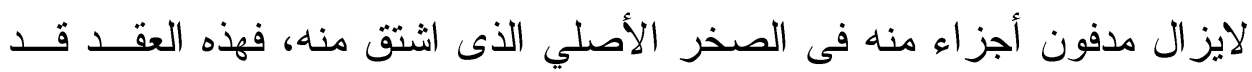
صنفت على أنها أحد مثتقيات عملية الإذابة السطحية، لهذا فهى تشير إلى أنها لم (Hume, 1925; Sanford, 1934; Embabi, 1976, 2004; Mostafa, تنقل من مو اقع اشتقاقها (2013 خاصة مناطق تكويني درنكة و المنيا (McBride et al; 1999). ويندرج تحت هذا النوع من إرسابات المواد المتبقية كدليل علـى الإذابــة الســــية وجــود الفرشات الحصوية السطحية وقروش الملائكة التى صنفت بهذه الدر اسة على أنها متبقيات كارست. لهذا يرجح أن نطاق التربة وغيرها من المواد المتبقية والحجر Epikarst الجيري المجوى التى ترتكز عليه هو جزء من نطاق قشرة الكارســــ zone تشير جميع الأدلة السابقة، الجيوموروفولوجية منها و الرســوبية، إلــى غياب أبي تأثير لكارست المحاليل الحرمائية على نشأة الممرات، وأن كل الأدلـــة ترجح التأثثر القوي لعملية الإذابة السطحية بفعل مباه الأمطار في تشكيل ســطح المنطقة، وأن ذلك قد تم من خلال عملية الإذابة العادية والانهريــار ات الناتجـــة عنها، مثل: انهيار ات الكهوف و الدولينات. ولكن السؤال الذي يطرح نفسه الآن هو: ما هي المحددات التي تحكمت في مواضع الإذابةٌ يمكن حصر المحدات الرئيسية التي تحكمت فـي اكسـاب المدرات مورفولوجيتها الحالية في عاملين رئيسيين: الأول هو الصدوع الرئيسية التي يغلب على اتجاهها الشمال الغربي-الجنوب الشرقي، و الشرقي- الغربـي،

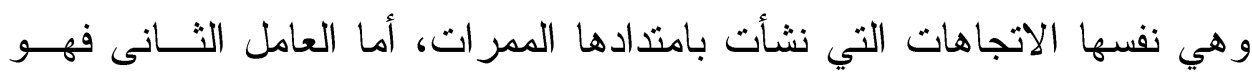


الطيات المقعرة التي أرجعتها در اسة Tewksbury et al. إلى عملية سحب أو 2017 خسف بفعل انهيار ات كهفية مرتبطة بتدفق المحاليل الحرمائية، وهي الميكانيكية التي لم تقبل في الدراسة الحالية. و الخلاصة أن المحددات البنيوية سواء كانـــ تكتونية أو غير تكتونية قد حددت أماكن الممرات. أما عن الميكانيكية البديلة المقترحة لتفسير نشأة الطيات غير التكتونيـة، و التي من خلالها يمكن تفسير نشاط الإذابة السطحية وتحت السطحية، سواء من خلال عملية الإذابة العادية أو من خلال الانهيار ات لاسيما المرتبطة بــالكهوف، فإن ذلك يمكن إرجاعه إلى الأزمة الميسينية المرتبطة بالبحر المتوســـ. فمـن المن المعروف أن الخانق الإيونيلى (وادي النيل في مصر) قد نشأ كنتيجة الانخفاض الحاد في مستوى سطح المياه بالبحر المتوسط والذي أطلق عليه الأزمة الميسينية (Said, الملحية "The Messenian Salinity Crisis التي تمت في نهاية عصر الميوسين (1981، وكان أحد أهم النتائج المترنبة على هذا الانخفاض هو إعادة تجديد نشاط عملية التعرية وما ترتب عليها من إعادة تشكيل السطح وتعميقه، ويعد التـأثير المباشر لهذه الأزمة هو نشأة الخانق الايونيلي لنهر النيل الأول الذي بلغ عمة النـهـ

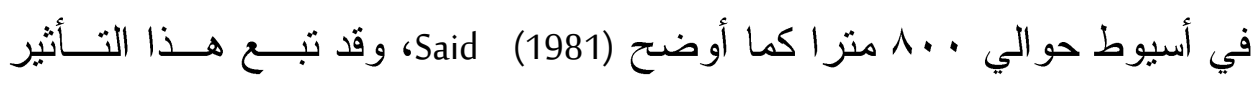
المباشر تأثنيرات غير مباشرة على سطح الهضاب المحيطة التي نشـطـ بهــا

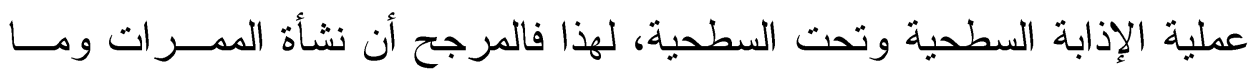
ارتبط بها من عمليات خسف سفلية أو إذابة سطحية هي نتاج غير مباشر للأزمة الميسينية وما ترتب عليها من نشأة الخانق الايونيلى الذي أعاد تجديد النشاط في الهضاب المحيطة. الجدير بالذكر أن هناك دراسات سابقة لم تستبعد الارتباط بين نشأة منخفضات الصحر اء الغربية بأحجامها الأكبر مــن الممــرات، والأزمـــة

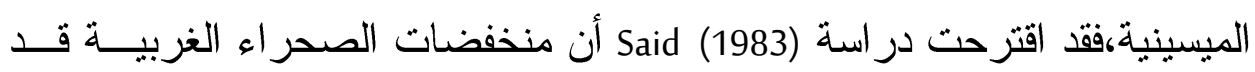
تكون أحد أهم هذه النتائج. 
في ضوء ما سبق يتضح من الدراسة الحالية أن الممرات قد نشأت بعـد نهاية عصر الميوسين، وقد استمر تطور ها حتى بداية الغمر البليوسيني الذي ملأ

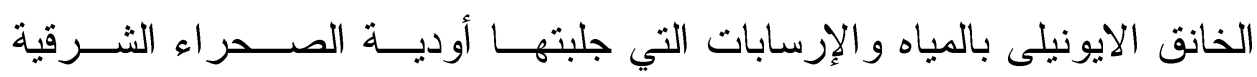

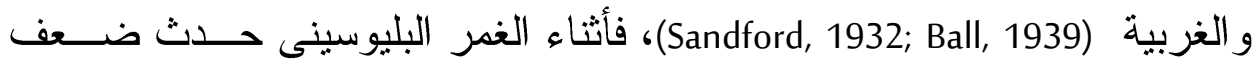

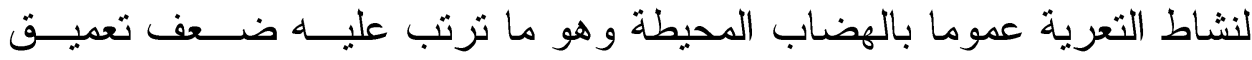
الممرات. ثم نشطت عمليات التعرية و التخفيض لا سيما بفعل الإذابة الســطحية مرة ثانية أثناء الفترات المطيرة خلال عصر البليستوسين وأوائـلـ الهولوســين

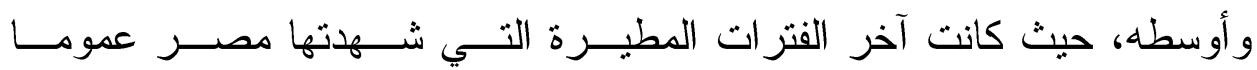
و الصحر اء الغربية بوجه خاص منذ ... .7 سنة تقريبا، ومنذ ذلك التاريخ سادت ظروف الجفاف التي لاتز ال مستمرة حتى الوقت الحالي.

\section{1: الاستنتتاجــات}

نشأت الممرات الضخمة بالصحر اء الغربية مع نهاية عصر الميوســين بفعل عملية الإذابة السطحية؛ لهذا تعد هذه الممرات أحد نواتج الكارست الــذي

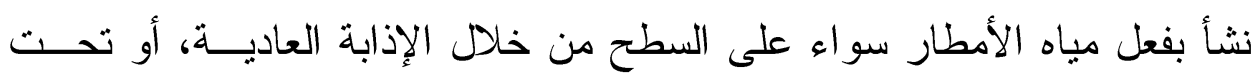
السطح من خلال الانهيار ات الكهفية، ولم تشر أي من الأدلة السطحية أو تحــــ السطحية إلى أي دور لتأثير كارست المحاليل الحرمائية. وترجع نشأة الممرات

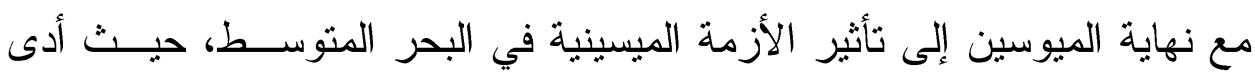

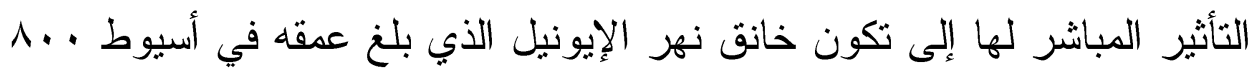
متر ا، أما التأثير غير المباشر فقد تمثل في تجديد نشاط التعرية بهضاب الحجـر الجيري المحيطة، وتعد الممرات أحد نواتج هذا التأثير غير المباشر من خــلال عمليتين: الأولى تمثلت في نشاط الإذابة السطحية لاســيما بامتــداد الصــدوع الشمالية الغربية-الجنوبية الشرقية و الفواصل، أما العملية الثانية فقد تمثلت فـي حدوث إذابة تحت سطحية نتج عنها خسف أدى إلى تكون طيات سحب (خسف) 
غير تكتونية، وقد انعكس ذلك على السطح، ومن المرجح أن عملية الانهيــارات الكهفية قد أدت دور ا مهما في تطور نشأة الممرات. أما عن التكوينات الحصوية

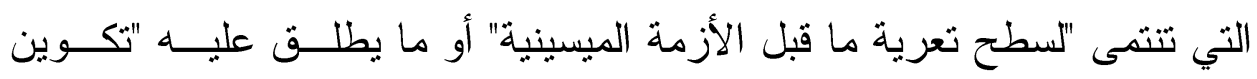

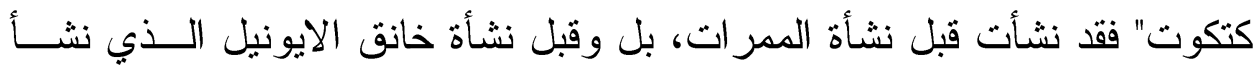
نهاية الميوسين. وقد ضعف نشاط تعميق الممرات بفعل الإذابة السطحية أثتــاء الغدر البليوسيني للخانق الإيونيلي؛ حيث ارتفع منسوب المباه الجوفية بالهضاب المحيطة مما أدى إلى ضعف نشاط التعرية عموما وعملية الإذابة بوجه خاص. إلا أن نشاط تطور الممرات قد عاد مرة ثانية أثثاء الفترات المطيرة في عصــر البليستوسين و أو ائل الهولوسين وأوسطه. 
1- أثرف أبو الفتوح مصطفى (1) • Y) جيومورفولوجية أثنكال الكارست فى منخفض الفرافرة، الصحر اء الغربية، مصر • رسالة دكتور اه غير منشورة. قسم الجغر افيا، كلية الآداب، جامعة عين شمس، القاهرة.

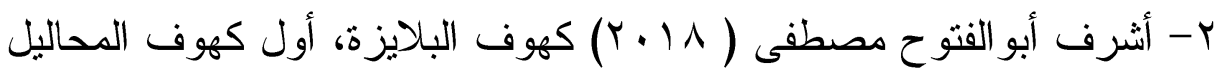

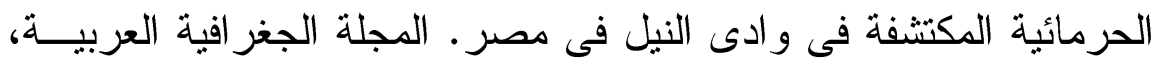

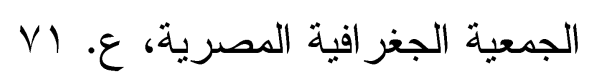

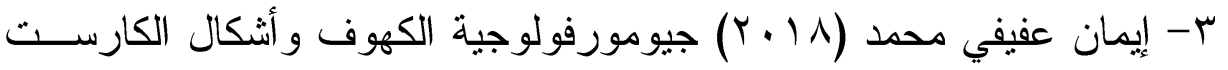

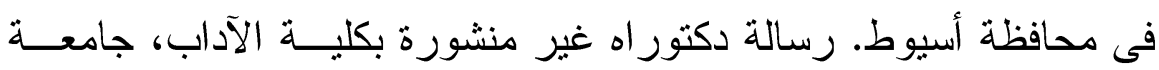
أسيوط، أسيوط.

\section{المراجع الأجنبية}

1-Abu El Ghar, M., Hussein, A., 2005. Post-depositional changes of the Lower-Middle Eocene limestone of the area between Assiut and Minia, west of the Nile Valley, Egypt. First International Conference on the Geology of the Tethys, November, Cairo University, pp. 37-57, Cairo, Egypt.

2- Abu Seif, El-Sayed Sedek, 2015. Geological evolution of Nile Valley, west Sohag, Upper Egypt: a geotechnical perception. Arab. J. Geosci. 8, PP.11049-11072.

3-Ahmed, S., 1993. Collapse and solution red breccia of the Issawia Sharq locality, Nile Valley, Upper Egypt. Egyptian Journal of Geology 37, 187-203.

4-Baajens, A., 1997. Geographical observations in the Western Desert of Egypt. Bull. Soc. Géogr.d'Égypte 70, 203-213. 
5- Ball, J., 1939. Contribution to the geography of Egypt. Survey \& Mines Department, Government Press, Cairo. 6- Brook, G., Embabi, N., Ashour, M., Edwards, R., Cheng, H., Cowart, J., A. Dabous, 2002. Djara cave in the Western Desert of Egypt: Morphology and evidence of Quaternary climatic change. Cave and Karst Science 2, 57-66.

7- Brooks, I., 2001. Possible Miocene catastrophic flooding in Egypt's Western Desert. Journal of African Earth Science 22, 325-333.

8-Caton-Thompson, G., Gardener, E., 1932. The Prehistoric geography of Kharga Oasis. Geographical Journal LXXX, 369-409.

9-El Aref, M., Abou Khadrah A., Lotfi, Z., 1987. Karst topography and karstification processes in the Eocene limestone plateau of El Bahariya Oasis, Western Desert, Egypt. Z. Geomorph. N. F 31, 45-64.

10- El-Haddad, A.A., Youssef , A. M., Mahran T. M., ElSharter, A. A., 2014. Material mapping in the Western Desert of Egypt using remote sensing and field investigation: a tool for managing urban development. The 7th Int. Conference for Development and the Environment in the Arab world, PP.527-538. Assiut, Egypt.

11- Embabi, N.S., 1967. A morphological study of the Kharga Oasis Depression, the Western Desert of Egypt. Unpublished Ph.D. thesis, University of Bristol. 
12- Embabi, N., 2004. The geomorphology of Egypt: Landforms and Evolution, Vol. 1, The Nile Valley and the Western Desert. The Egyptian Geographical Society, Cairo.

13- Hume, W., 1925. Geology of Egypt, Vol. 1, Survey of Egypt. Government Press, Ministry of Finance, Cairo.

14- Issawi, B., El Hinnawi, M., Francis, M., Mazhar, A., 1999. The Phanerozoic Geology of Egypt: a Geodynamic Approach. Egyptian Geological Survey, Cairo, p. 462.

15- Kindermann, K., Bubenzer, O., Nussbaum, S., Riemer H., Darius F., Pollath N., Smettan, U., 2006. Palaeoenvironment and Holocene land use of Djara, Western Desert of Egypt. Quaternary Science Reviews 25, 16191637.

16- Klimchouk, A.B., Ford, D., Palmer, A. and Dreybrodt, W. (Eds.). 2000. Speleogenesis: Evolution of karst aquifers. National Speleological Society, Huntsville, 527 p.

17- Klimchouk, A., 2007. Hypogene Speleogenesis: Hydrogeological and Morphometric Perspective. National Cave and Karst Research Institute, Special Paper No. 1, Carlsbad, NM, 106 p.

18- Klitszch, E., List, F.K., Pohlmann, G., 1987. Geological Map of Egypt. Conoco Coral and Egyptian General Petroleum Company, Cairo, Egypt. 24 Sheets, scale 1:500 000 . 
19- Kuper, R., 1996, Between the Oases and the Nile-Djara: Rohlfs Cave in the Western Desert, Interregional Contacts in the Later Prehistory of Northeastern Africa. Archaeological Museum, Poznan, pp. 81-91.

20- List, F.K., Meissner, B., Pohlmann, G., 1990. Application of remote sensing and satellite cartography in preparation of the new geological map. In: Said, R. (Ed.), The Geology of Egypt. A.A. Balkema, Rotterdam. Scale 1:500 000, pp. $27-44$.

21- McBride E., Abdel-wahab, A., El-Younsy, A., 1999. Origin of spheroidal chert, Drunka Formation (Lower Eocene), Egypt. Sedimentology 46, 733-755.

22- Mostafa, A. A., Paleokarst features on the limestone plateau west of Assiut, the Western Desert, Egypt. 2nd Symposium on Living with Landscape, Egyptian Geographic Society \& Faculty of Arts, Damanhur Campus, Alexandria University, Egypt, 31st October-5th November, 2009, p.48.

23- Mostafa, A. A., 2012. Mega corridors of the Western Desert of Egypt: Morphology, origin, and its historic role. (Abstract) 7th International Conference of the Dakhleh Oasis Project New Developments in the Archaeology of the Egyptian Western Desert and its Oases. 20th-24th June. P.19, Leiden, Netherland. 
24- Mostafa, A. A., 2013. Paleokarst Shafts in the Western Desert of Egypt: A unique landscape. ACTA CARSOLOGICA 42, 49-60.

25- Said, R., 1962. Geology of Egypt, Elsevier Publishing Co. Amesterdam-New York.

26- Said, R., 1981. The Geological Evolution of the River Nile. Springer-Verlag, New York.

27- Said, R., 1983a. Proposed classification of the Quaternary of Egypt. Journal of African Earth Sciences 1, 41-45.

28- Said, R., 1983b. Remarks on the origin of the landscape of the eastern Sahara. Journal of African Earth Sciences 1, 153-158.

29- Said, R., (Ed.), 1990. The geology of Egypt. Balkema, Rotterdam.

30- Sandford, K., 1934. Palaeolithic Man and the Nile Valley in Upper and Middle Egypt, Chicago University Press, Oriental Institute Publication, 3, 131 p.

31- Shabaan, S. H., 2000. Shallow seismic refraction exploration for engineering site investigations in the area west of Assiut city, Middle Egypt. M.sc. Thesis, Department of Geology, Faculty of Science, Assiut University, Assiut.

32- Sokkar, A. M., 1991. Geomorphology, petrological, and mineralogical studies on the carbonate sediments between Baharia-Farafra, Western Desert, Egypt, M.sc. Thesis, Department of Geology, Faculty of science, Cairo University, Cairo. 
33- Sweeting, M., 1972. Karst Landforms.-Macmillan, London.

34- Tarabees, E. A., Tewksbury, B. J., Mehrtens, C. J., Younis, A., 2017. Audio-magnetotelluric surveys to constrain the origin of a network of narrow synclines in Eocene limestone, Western Desert, Egypt. J. Afr. Earth Sci. 136, PP.168-175.

35- Tewksbury, B. J., Tarabees, E. A., Mehrtens, C. J., 2017. Origin of an extensive network of non-tectonic synclines in Eocene limestones of the Western Desert, Egypt. J. Afr. Earth Sci. 136, PP.148-167.

36- UNESCO, 1972. Glossary and Multilingual Equivalents of Karst Terms. United Nations Educational. Scientific. and Cultural Organization. Paris, France.

37- Youssef, M., Mansour, H., Philobbos, E., 1982. Contribution to the Geology of the area northwest of Assiut, Egypt. Bulletin of the faculty of science. Assiut University, 1, 335-354.

38- Zaki, A. S., R. Giegengack (2016). Inverted topography in the southeastern part of the Western Desert of Egypt. Journal of African Earth Sciences 121, 56-61. 